\title{
Dietary fibre, whole grains, and risk of colorectal cancer: systematic review and dose-response meta-analysis of prospective studies
}

\author{
(c) $\underset{\text { (1) () }}{\mathrm{gy}}$ OPEN ACCESS
}

\author{
Dagfinn Aune research associate ${ }^{1}$, Doris S M Chan research associate ${ }^{1}$, Rosa Lau research \\ associate $^{1}$, Rui Vieira data manager ${ }^{1}$, Darren C Greenwood senior lecturer in biostatistics ${ }^{2}$, Ellen \\ Kampman professor of diet and cancer ${ }^{3}$, Teresa Norat principal investigator ${ }^{1}$
}

${ }^{1}$ Department of Epidemiology and Biostatistics, School of Public Health, Imperial College London, St Mary's Campus, London W2 1PG, UK; ${ }^{2}$ Biostatistics Unit, Centre for Epidemiology and Biostatistics, University of Leeds, Leeds, UK; ${ }^{3}$ Division of Human Nutrition, Wageningen University and Research Centre, Wageningen, Netherlands

\begin{abstract}
Objective To investigate the association between intake of dietary fibre and whole grains and risk of colorectal cancer.

Design Systematic review and meta-analysis of prospective observational studies.

Data sources PubMed and several other databases up to December 2010 and the reference lists of studies included in the analysis as well as those listed in published meta-analyses.

Study selection Prospective cohort and nested case-control studies of dietary fibre or whole grain intake and incidence of colorectal cancer.

Results 25 prospective studies were included in the analysis. The summary relative risk of developing colorectal cancer for $10 \mathrm{~g}$ daily of total dietary fibre (16 studies) was 0.90 (95\% confidence interval 0.86 to $\left.0.94, I^{2}=0 \%\right)$, for fruit fibre $(n=9)$ was $0.93\left(0.82\right.$ to $\left.1.05, l^{2}=23 \%\right)$, for vegetable fibre $(n=9)$ was $0.98\left(0.91\right.$ to $\left.1.06, l^{2}=0 \%\right)$, for legume fibre $(n=4)$ was $0.62\left(0.27\right.$ to $\left.1.42, I^{2}=58 \%\right)$, and for cereal fibre $(n=8)$ was $0.90\left(0.83\right.$ to $\left.0.97, l^{2}=0 \%\right)$. The summary relative risk for an increment of three servings daily of whole grains $(n=6)$ was $0.83(0.78$ to 0.89 , $\mathrm{I}^{2}=18 \%$ ).
\end{abstract}

Conclusion A high intake of dietary fibre, in particular cereal fibre and whole grains, was associated with a reduced risk of colorectal cancer. Further studies should report more detailed results, including those for subtypes of fibre and be stratified by other risk factors to rule out residual confounding. Further assessment of the impact of measurement errors on the risk estimates is also warranted.

\section{Introduction}

Colorectal cancer is the third most common type of cancer, with 1.2 million new cases diagnosed in 2008 worldwide, accounting for about $9.7 \%$ of all cases of cancer. ${ }^{1}$ Evidence from ecological studies, migrant studies, and secular trend studies suggest that environmental risk factors are of major importance in the cause of colorectal cancer. ${ }^{2-4}$ Dietary factors have been suspected as important, but only intakes of red and processed meat and alcohol are considered to be convincing dietary risk factors for colorectal cancer. ${ }^{5}$

In the 1970s, Burkitt proposed the hypothesis that dietary fibre reduces the risk of colorectal cancer, based on the observation of low rates of such cancer among rural Africans who ate a diet with a high fibre content. ${ }^{6}$ Several plausible mechanisms have been proposed to explain the hypothesis, including increased stool bulk and dilution of carcinogens in the colonic lumen, reduced transit time, and bacterial fermentation of fibre to short chain fatty acids. ${ }^{7}$ However, although many epidemiological studies have investigated the association between fibre intake and risk of colorectal cancer, the results have not been consistent and the possibility of residual confounding by folate intake remains a controversial issue. ${ }^{8}$ Case-control studies have generally shown a protective association, ${ }^{910}$ whereas the results from cohort studies have been mixed. ${ }^{811-31}$ In addition, it is not clear whether only specific types or sources of fibre are associated with the risk. Although initial cohort studies generally reported no significant association between fibre intake and risk of colorectal cancer, the hypothesis regained interest when the 
European Prospective Investigation into Cancer and Nutrition (EPIC) study reported a linear decrease in the risk of colorectal cancer with increasing fibre intake. ${ }^{19}$ A subsequent pooled analysis of 13 North American and European cohort studies (not including the EPIC study) reported an $18 \%$ increased risk of colorectal cancer with low fibre intake $(<10 \mathrm{~g} /$ day $v 10-15$ $\mathrm{g} /$ day), but no further reductions in risk were observed with higher intake. ${ }^{31}$ More recently, results from additional large cohort studies ${ }^{23-30}$ have been published and, together with the EPIC study, included more than 1.7 million participants and 12 000 cases and included several studies from Asian populations. ${ }^{2324} 26{ }^{30}$ With such a large number of additional studies we had sufficient statistical power to clarify the dose-response relation between fibre intake and risk of colorectal cancer. In addition we examined whether specific types of fibre are associated with risk.

Whole grains are a major source of dietary fibre and contain germ, endosperm, and bran, in contrast with refined grains that contain only the endosperm. The germ and bran contain numerous nutrients, which are removed during the refining process. In addition, whole grains are a major source of several vitamins, minerals, and phytochemicals, which have anticancer properties and could plausibly influence the risk of colorectal cancer by several potential mechanisms. ${ }^{32}$ An earlier review and meta-analysis of case-control studies of whole grain intake and colorectal cancer and polyps reported a summary odds ratio of 0.79 for the highest versus the lowest intake. ${ }^{33}$ However, the interpretation of case-control studies is hampered by possible recall and selection biases, which make it difficult to draw firm conclusions. Over the past decade results from several cohort studies have been published on whole grain intake and risk of colorectal cancer, with mixed results. $.^{16} 22^{27} 34-39$ Some studies suggested no association, ${ }^{162034} 36$ whereas others reported an inverse association with higher whole grain intake. 252735 37-39 To clarify the association between dietary fibre and whole grain intake and risk of colorectal cancer we carried out a systematic review and meta-analysis of published prospective studies. We also did meta-regression and sensitivity analyses to evaluate potential sources of heterogeneity in the analyses.

\section{Methods}

Several reviewers at Wageningen University carried out the literature search and extracted data up to December 2005. They searched several databases, including PubMed, Embase, CAB Abstracts, ISI Web of Science, BIOSIS, Latin American and Caribbean Center on Health Sciences Information, Cochrane library, Cumulative Index to Nursing and Allied Health Literature, the Allied and Complementary Medicine Database, National Research Register, and In Process Medline. As all the relevant prospective studies were identified by the PubMed searches the protocol was modified and only PubMed was used for the updated searches from January 2006 to December 2010. No language restrictions were imposed. This review was done as part of the Continuous Update Project of the World Cancer Research Fund and has been published online (www.wcrf.org/ PDFs/Colorectal-cancer-CUP-report-2010.pdf). A predefined protocol was used for the review (www.dietandcancerreport. org/downloads/SLR_Manual.pdf) and we followed standard criteria for meta-analyses of observational studies. ${ }^{40}$ Abstracts, grey literature, and unpublished results or information were not included. We also searched the reference lists of the studies that were included in our analysis as well as those listed in the published meta-analyses. ${ }^{33} 41$

\section{Study selection}

To be included studies had to have a prospective cohort, case-cohort, or nested case-control design and investigate the association between dietary fibre or whole grain intake and incidence of colorectal cancer. We excluded retrospective case-control studies and cross sectional studies. The publication had to include estimates of the relative risk (hazard ratio, risk ratio) with the $95 \%$ confidence intervals. For the dose-response analysis, a quantitative measure of intake and the total number of cases and person years had to be provided. When several publications were from the same study we selected the publication with the largest number of cases. We identified 40 potentially relevant full text publications..$^{811-30}$ 34-39 42-54 $\mathrm{We}$ excluded seven that reported mean exposure only, ${ }^{42-48}$ seven that were duplicate publications, ${ }^{19}{ }^{49-54}$ and one that was on mortality from colorectal cancer. ${ }^{34}$ Two publications that were included in the dietary fibre analyses reported on specific whole grain foods, not overall intake, and we excluded these from the whole grain analysis. ${ }^{16}{ }^{20}$ For the dose-response analysis we further excluded two publications that reported results only for the highest versus the lowest levels of intake, ${ }^{30}{ }^{37}$ and two publications that did not report quantities of intake. ${ }^{11} 15$

\section{Data extraction}

From each study we extracted data on the first author's last name, year of publication, country where the study was done, study name, follow-up period, sample size, sex, age, number of cases, method of dietary assessment (type, number of food items, and whether the assessment method had been validated), exposure (by type of outcome), quantity of intake, relative risks and $95 \%$ confidence intervals for the highest versus the lowest intake, and variables adjusted for in the analysis. Several reviewers at Wageningen University carried out the search and extracted data of articles published up to December 2005 during the systematic literature review for the World Cancer Research Fund and Association for International Cancer Research report (www.dietandcancerreport.org/downloads/SLR/Colon_and_ Rectum_SLR.pdf). Two of the authors (DSMC and RL) did the search from January 2006 to December 2010. Three authors (DSMC, RL, and DA) extracted the data into a database, and two authors (TN and DA) checked these for accuracy.

\section{Statistical analysis}

We used random effects models to calculate summary relative risks and $95 \%$ confidence intervals for the highest versus the lowest levels of dietary fibre and whole grain intake and for the dose-response analysis. The average of the natural logarithm of the relative risks was estimated and we weighted the relative risk from each study by the inverse of its variance. A two tailed $\mathrm{P}<0.05$ was considered statistically significant. For studies that reported results separately for colon and rectal cancer or for men and women separately, we combined the estimates using a fixed effects model to obtain an overall estimate for colorectal cancer or both sexes combined.

We used a previously described method ${ }^{55}$ for the dose-response analysis and computed study specific slopes (linear trends) and $95 \%$ confidence intervals from the natural logs of the relative risks and confidence intervals across categories of dietary fibre and whole grain intake. The method requires that the distribution of cases and person years or non-cases and the relative risks with the variance estimates are known for at least three quantitative categories of use. We estimated the distribution of cases or person years in studies that did not report these but reported the total number of cases or person years if the results 
were analysed by quantiles (and could be approximated)—for example, the total number of person years was divided by 5 when data were analysed by quintiles to derive the number of person years in each fifth. We assigned the median or mean level of dietary fibre or whole grain intake in each category to the corresponding relative risk for each study. For studies that reported the intake by ranges of intake we estimated the midpoint in each category by calculating the average of the lower and upper bound. When the highest category was open ended we assumed the length of the open ended interval to be the same as that of the adjacent interval. When the lowest category was open ended we set the lower boundary to zero. If the intakes were reported in densities (servings per $1000 \mathrm{kcal}$ ) we recalculated the reported intakes to absolute intakes using the mean or median energy intake. ${ }^{18} 212728$ In studies that reported the whole grain intake in grams daily we used $30 \mathrm{~g}$ as a serving size for recalculation of the intakes to a common scale (servings daily). The dose-response results in the forest plots are presented for a $10 \mathrm{~g}$ daily increment for dietary fibre and for an increment of three servings daily $(90 \mathrm{~g})$ for whole grains. We examined a potential non-linear dose-response relation between dietary fibre and whole grain intake and colorectal cancer by using fractional polynomial models. ${ }^{56} \mathrm{We}$ determined the best fitting second order fractional polynomial regression model, defined as the one with the lowest deviance. A likelihood ratio test was used to assess the difference between the non-linear and linear models to test for non-linearity. ${ }^{57}$

Heterogeneity between studies was assessed by the Q test and $\mathrm{I}^{2}$ statistic. ${ }^{58} \mathrm{I}^{2}$ is the amount of total variation that is explained by variation between studies. We did not use a score to assess study quality but in subgroup analyses we determined whether indicators of study quality, such as study size, number of cases, duration of follow-up, and adjustment for confounders modified the results. Heterogeneity between subgroups was evaluated by meta-regression.

Publication bias was assessed with Egger's test ${ }^{59}$ and Begg's test, ${ }^{60}$ with the results considered to indicate publication bias when $\mathrm{P}<0.10$. In addition, we visually explored funnel plots for asymmetry. We carried out sensitivity analyses excluding one study at a time to explore whether the results were driven by one large study or by a study with an extreme result.

\section{Results \\ Dietary fibre}

Twenty one prospective studies ${ }^{811-18 ~ 20-30} 36$ were identified and included in the analysis of the highest versus the lowest intake of dietary fibre and risk of colorectal cancer, 18 of which $^{812-14 \text { 16-18 20-29 } 36}$ were included in the dose-response analyses (table $1 \Downarrow$, fig $1 \Downarrow$ ). Twelve of the studies were from the United States, five from Europe, and four from Asia. Table 1 summarises the characteristics of the included studies. The ranges of intake varied: $6.3-21.4 \mathrm{~g} / \mathrm{day}$ for total dietary fibre, 1.8-15.5 g/day for fruit fibre, $1.9-16.8 \mathrm{~g} /$ day for vegetable fibre, 3.0-16.9 g/day for cereal fibre, and 1.3-3.8 g/day for legume fibre (results not shown).

\section{Total dietary fibre High versus low intake}

Nineteen prospective studies (18 publications) were included in the analysis of high versus low intake of total dietary fibre and risk of colorectal cancer (table 1). ${ }^{811} 1215-18$ 20-30 The summary relative risk was 0.88 (95\% confidence interval 0.82 to 0.94 ), with no evidence of heterogeneity $\left(\mathrm{I}^{2}=0 \%, \mathrm{P}=0.48\right.$, see web extra figure 1a).

\section{Dose-response analysis}

Sixteen prospective studies (15 publications) $)^{812} 16-18$ 20-29 were included in the dose-response analysis, with 14514 cases among 1985552 participants. The summary relative risk was 0.90 ( 0.86 to 0.94 ) for each $10 \mathrm{~g} /$ day intake, with no significant heterogeneity $\left(\mathrm{I}^{2}=0 \%, \mathrm{P}=0.48\right.$, fig $\left.2 \Downarrow\right)$. A statistically significant inverse association was seen for colon cancer ${ }^{8} 12-1421232426-2936$ (13 studies, summary relative risk $0.89,0.81$ to $0.97, \mathrm{I}^{2}=35 \%$, $\mathrm{P}=0.11)$ but not for rectal cancer ${ }^{81221232426-29}$ (10 studies, 0.91, 0.83 to $1.03, \mathrm{I}^{2}=15 \%, \mathrm{P}=0.31$ ), although evidence was lacking for heterogeneity between subsites ( $\mathrm{P}=0.86$, see table 3 ). Publication bias was not evident with either Egger's test $(\mathrm{P}=0.62)$ or Begg's test $(\mathrm{P}=0.56)$. In a sensitivity analysis excluding one study at a time, the summary relative risk for colorectal cancer ranged from 0.89 (0.85 to 0.93$)$ when the National Institutes of Health-American Association for Retired Persons (NIH-AARP) Diet and Health Study was excluded to 0.91 (0.88 to 0.96 ) when the EPIC study was excluded. A non-linear association was not evident between intake of total dietary fibre and risk of colorectal cancer $(\mathrm{P}=0.32$ for non-linearity, fig 2).

\section{Fruit fibre}

\section{High versus low intake}

Nine cohort studies (eight publications) $81718212226-28$ were included in the analysis of high versus low intake of fruit fibre and risk of colorectal cancer. The summary relative risk was 0.94 (0.85 to 1.04; see also web extra figure $2 \mathrm{a})$, with little evidence of heterogeneity $\left(\mathrm{I}^{2}=39 \%, \mathrm{P}=0.11\right)$.

\section{Dose-response analysis}

Nine cohort studies (eight publications) $)^{8} 17182122$ 26-28 were included in the dose-response analysis of fruit fibre and risk of colorectal cancer, with 9930 cases among 1514871 participants. The summary relative risk for each $10 \mathrm{~g} /$ day intake was 0.93 ( 0.82 to 1.05 , fig $3 \Downarrow$ ), with little evidence of heterogeneity $\left(\mathrm{I}^{2}=23 \%, \mathrm{P}=0.24\right)$. Publication bias was not evident with Egger's test $(\mathrm{P}=0.83)$ or Begg's test $(\mathrm{P}=0.47)$. The summary relative risk ranged from 0.87 ( 0.78 to 0.96$)$ when the NIH-AARP Diet and Health Study was excluded to 0.95 (0.84 to 1.07) when the Nurses' Health Study was excluded.

\section{Vegetable fibre}

\section{High versus low intake}

Nine cohort studies (eight publications) $)^{8} 17182122$ 26-28 were included in the analysis of high versus low intake of vegetable fibre and risk of colorectal cancer. The summary relative risk was 0.98 ( 0.91 to 1.06 , also see web extra figure $2 \mathrm{~b}$ ), with no evidence of heterogeneity $\left(\mathrm{I}^{2}=0 \%, \mathrm{P}=0.48\right)$.

\section{Dose-response analysis}

Nine cohort studies (eight publications) $81718212226-28$ were included in the dose-response analysis of vegetable fibre and risk of colorectal cancer, with 9930 cases among 1514871 participants. The summary relative risk for each $10 \mathrm{~g} /$ day intake was 0.98 (0.91 to 1.06 , fig 3$)$, with no evidence of heterogeneity $\left(\mathrm{I}^{2}=0 \%, \mathrm{P}=0.60\right)$. Publication bias was not evident with Egger's test $(\mathrm{P}=0.51)$ or Begg's test $(\mathrm{P}=0.92)$. The summary relative risk ranged from 0.96 ( 0.89 to 1.04 ) when the Nurses' Health 
Study was excluded to 1.02 (0.94 to 1.10) when the Multiethnic Cohort Study was excluded.

\section{Legume fibre}

\section{High versus low intake}

Four cohort studies ${ }^{81822} 27$ were included in the analysis of high versus low intake of legume fibre and risk of colorectal cancer. The summary relative risk was 0.89 ( 0.78 to 1.02 , see also web extra figure $2 \mathrm{c})$, with moderate heterogeneity $\left(\mathrm{I}^{2}=40.8 \%\right.$, $\mathrm{P}=0.17)$.

\section{Dose-response analysis}

Four cohort studies ${ }^{81822} 27$ were included in the dose-response analysis of legume fibre intake and risk of colorectal cancer, with 5405 cases among 1095056 participants. The summary relative risk for each $10 \mathrm{~g}$ /day intake was $0.62(0.27$ to 1.42 , fig $3)$, with moderate to high heterogeneity $\left(\mathrm{I}^{2}=58 \%, \mathrm{P}=0.07\right)$. The summary relative risk ranged from 0.38 (0.08 to 1.87) when excluding the NIH-AARP Diet and Health Study to 0.84 (0.65 to 1.09) when excluding the Women's Health Study.

\section{Cereal fibre}

\section{High versus low intake}

Eight cohort studies (seven publications) 8171821222728 were included in the analysis of high versus low intake of cereal fibre and risk of colorectal cancer. The summary relative risk was 0.90 ( 0.83 to 0.96 , also see web extra figure $2 \mathrm{~d}$ ), with no significant heterogeneity $\left(\mathrm{I}^{2}=0 \%, \mathrm{P}=0.94\right)$.

\section{Dose-response analysis}

Eight cohort studies (seven publications) ${ }^{8} 171821222728$ were included in the dose-response analysis of cereal fibre and risk of colorectal cancer, with 9487 cases among 1471756 participants. The summary relative risk for each $10 \mathrm{~g} /$ day intake was 0.90 ( 0.83 to 0.97 , fig 3 ), with no evidence of heterogeneity $\left(\mathrm{I}^{2}=0 \%, \mathrm{P}=0.78\right)$. Publication bias was not evident with Egger's test $(\mathrm{P}=0.90)$ or Begg's test $(\mathrm{P}=1.00)$. The summary relative risk ranged from 0.85 (0.76 to 0.95 ) when the Multiethnic Cohort Study was excluded to 0.93 (0.85 to 1.03 ) when the NIH-AARP Diet and Health Study was excluded.

\section{Whole grains}

Seven cohort studies were included in the analysis of total whole grain intake and risk of colorectal cancer (table $2 \Downarrow$, fig $1 \Downarrow){ }^{25}{ }^{27}{ }^{35-39}$ Two studies were from Europe and the other five from the United States (table 2). Total whole grains included whole grain rye breads, whole grain breads, oatmeal, whole grain cereals, high fibre cereals, brown rice, and porridge. The range of whole grain intake varied from and 61-128 g/day (results not shown).

\section{High versus low intake}

Four cohort studies ${ }^{25} 2735$ were included in the analysis of high versus low intake of whole grains and risk of colorectal cancer. The summary relative risk was $0.79(0.72$ to 0.86$)$, with no evidence of heterogeneity $\left(\mathrm{I}^{2}=0 \%, \mathrm{P}=0.98\right.$, see web extra figure 1b). The results for colon and rectal cancer were similar: summary relative risks $0.82\left(0.72 \text { to } 0.92, \mathrm{I}^{2}=23 \%, \mathrm{P}=0.27\right)^{2735-38}$ and $0.80\left(0.59\right.$ to $\left.1.07, \mathrm{I}^{2}=58 \%, \mathrm{P}=0.10\right) .{ }^{27}{ }^{35}{ }^{38}$ The results for rectal cancer were, however, not statistically significant.

\section{Dose-response analysis}

Six studies (five publications) 2527353839 were included in the dose-response analysis, with a total of 7941 cases among 774 806 participants. The summary relative risk for colorectal cancer with an increment of three servings daily ( $90 \mathrm{~g} /$ day) of whole grains was 0.83 ( 0.78 to 0.89 , fig $4 \Downarrow)$, with no evidence of heterogeneity $\left(\mathrm{I}^{2}=18 \%, \mathrm{P}=0.30\right)$. The summary relative risk for colon cancer ${ }^{27} 35{ }^{36}$ was 0.86 (0.79 to 0.94$)$, with no evidence of heterogeneity $\left(\mathrm{I}^{2}=0 \%, \mathrm{P}=0.42\right)$, and for rectal cancer ${ }^{27} 3538$ was 0.80 (0.56 to 1.14$)$, with substantial heterogeneity $\left(I^{2}=91 \%\right.$, $\mathrm{P}<0.001$, table 4$)$. In a sensitivity analysis excluding one study at a time, no particular study explained the results for colorectal cancer; the summary relative risk ranged from 0.82 (0.77 to 0.88 ) when the Swedish Mammography Study was excluded to 0.86 (0.80 to 0.92) when the NIH-AARP Diet and Health Study was excluded. Publication bias was not evident with Egger's test $(\mathrm{P}=0.54)$ or Begg's test $(\mathrm{P}=1.00)$, although the number of studies was low. However, the funnel plots did not suggest asymmetry. A non-linear association between whole grain intake and risk of colorectal cancer was not indicated ( $\mathrm{P}=0.26$, fig 4).

\section{Subgroup, sensitivity, and meta-regression analyses}

In subgroup analyses defined by sex, subsite, adjustment for confounders, number of cases, duration of follow-up, geographical location, and range of intake, total dietary fibre intake was inversely associated with risk of colorectal cancer in most subgroups, with no evidence of significant heterogeneity between subgroups with meta-regression analyses (table $3 \Downarrow$ ). Similar results were observed for intake of cereal fibre and whole grains (table $4 \Downarrow$ ). Intake of fruit fibre was not significantly associated with risk of colorectal cancer in most subgroup analyses. In the subgroups of studies that adjusted for alcohol intake and body mass index or weight, however, inverse associations were significant, with evidence of heterogeneity between subgroups $(\mathrm{P}=0.04$, table 3$)$. When stratified by the range of intake, an inverse association was observed for intake of fruit fibre in studies with a range of $10 \mathrm{~g} /$ day or more but not among studies with a range of $10 \mathrm{~g}$ /day or less $(\mathrm{P}=0.04$ for heterogeneity), but evidence of a difference in the results for the other fibre types was lacking when stratified by the range of intake (tables 3 and 4). Intake of vegetable fibre consistently was not associated with risk of colorectal cancer in subgroup analyses (table $3 \Downarrow$ ). Too few studies of legume fibre precluded any meaningful subgroup analyses.

In addition, the effect on the results of excluding studies from the dose-response analysis was explored. When the analysis of high versus low intake was restricted to the studies that were included in the dose-response analysis of total dietary fibre, the summary relative risk was $0.86\left(0.80\right.$ to $0.92, \mathrm{I}^{2}=0 \%, \mathrm{P}=0.46$ for heterogeneity), similar to the original analysis including all studies.

The influence on the results of the method used to estimate total fibre intake was assessed. For the eight studies ${ }^{17} 212224$ 26-28 using the Association of Official Analytical Chemists method, the summary relative risk was $0.91\left(0.85\right.$ to $0.97, \mathrm{I}^{2}=13.3 \%, \mathrm{P}=0.33$ for heterogeneity), for the four studies ${ }^{81621}$ using the Englyst method it was $0.91\left(0.81\right.$ to $1.02, \mathrm{I}^{2}=37.0 \%, \mathrm{P}=0.19$ for heterogeneity), and for the six studies ${ }^{12} 1820232529$ with an unknown method it was 0.93 ( 0.86 to $1.00, \mathrm{I}^{2}=0 \%, \mathrm{P}=0.89$ for heterogeneity). In this sensitivity analysis no heterogeneity was found between subgroups ( $\mathrm{P}=0.39$ for heterogeneity). In addition, in one study the results did not differ materially between the two methods. ${ }^{21}$ 


\section{Discussion}

Our meta-analysis supports an inverse association between intake of dietary fibre, cereal fibre, and whole grains and risk of colorectal cancer, but we found no significant evidence for an association with intake of fibre from fruit, vegetables, or legumes.

\section{Comparison with other studies}

Our results for total dietary fibre are consistent with a previous meta-analysis of case-control studies, which found an inverse association between fibre intake and risk of colorectal cancer. Our results, based on prospective studies, are not, however, as strong as the previous results from case-control studies. ${ }^{9}$ The size of the summary estimates from our analyses is more in line with those of a pooled analysis of cohort studies, ${ }^{31}$ which found an $18 \%$ increased risk among people with a low intake of dietary fibre $(<10 \mathrm{~g} /$ day). In that analysis, however, no further reduction in risk occurred with higher intake of fibre, whereas we observed a linear inverse association with increasing intake, such as shown in the EPIC study. ${ }^{8}$ Several differences between our analysis and the pooled analysis could explain the differences between the results. For example, although some overlap occurs between the studies included in the two analyses, some differences also exist. Our dose-response analysis included results from seven ${ }^{16-18} 212225$ of the 13 studies in the Pooling Project of Prospective Studies of Diet and Cancer, but included nine additional studies ${ }^{8} 1220232426-29$ not included in the pooled analysis, some of which were large. Thus our analysis included more than 14000 cases among 1.9 million participants compared with 8000 cases among 700000 participants in the pooled analysis. It is therefore possible that these additional studies contributed to a better assessment of the dose-response relation between fibre intake and risk of colorectal cancer. In line with the pooled analysis we found no evidence for an association between fruit or vegetable fibre and risk of colorectal cancer. However, in a previous meta-analysis of prospective studies we showed a reduction in risk with high intake of fruit and vegetables, ${ }^{61}$ suggesting the potential role of components other than fibre in fruits and vegetables in explaining this result. In addition, we cannot exclude the possibility that the range of fruit fibre intake was too low to detect an inverse association in the overall analysis, although no difference in the summary estimates was observed for the other fibre types when stratified by the range of intake. Inverse associations were evident between intakes of cereal fibre and whole grain and risk of colorectal cancer in our analysis, and the results for whole grain intake are consistent with a previous meta-analysis of case-control studies, which reported a $20 \%$ reduction in risk with high whole grain intake. ${ }^{33}$ The pooled analysis found a marginally significant inverse association between whole grain intake and colorectal cancer: pooled relative risk $0.92(95 \%$ confidence interval 0.84 to 1.00$).{ }^{31}$ In contrast to our results, the Women's Health Initiative Trial did not find a reduction in risk of colorectal cancer among participants who were randomised to an intervention with increased intakes of fruits, vegetables, grains, and fibre and reductions in fat intake. ${ }^{62}$ However, fibre intake increased by only $2.5 \mathrm{~g} /$ day from baseline to the three year follow-up, from 15.4 to $17.9 \mathrm{~g} /$ day, whereas the intake in the comparison group did not materially change (from 15.4 to $14.8 \mathrm{~g} /$ day). Thus the changes in fibre intake in that trial may have been too small to significantly reduce the risk of colorectal cancer. Given that our results show a $10 \%$ reduction in risk of colorectal cancer for each $10 \mathrm{~g}$ intake of fibre daily, only a 2-3\% reduction in risk would be expected with such a small increase in fibre intake.

\section{Limitations of the study}

Our meta-analysis has limitations that affect the interpretation of the results. It is possible that the weak inverse associations between dietary fibre or whole grain intake and risk of colorectal cancer could result from unmeasured or residual confounding by other dietary or lifestyle factors. Higher intakes of dietary fibre and whole grain are typically associated with other health behaviours, such as higher intakes of calcium and folate; higher levels of physical activity; lower prevalence of smoking, overweight, or obesity; and lower intakes of alcohol and red and processed meat. ${ }^{27} 27$ Many but not all of the studies adjusted for potential confounding factors, although not all potential confounders were adjusted for in every study. In analyses stratified by adjustment for confounding factors, however, we found that the association between dietary fibre, cereal fibre, and whole grains persisted in most subgroups, with adjustment for potential confounding factors. In addition, in meta-regression analyses evidence that the results for these exposures differed significantly whether confounders had been adjusted for or not was lacking. Only in the analysis of fruit fibre was heterogeneity evident between studies that did or did not adjust for body mass index or weight and alcohol intake, with significant inverse associations among the studies with such adjustments. None of the included studies reported results stratified by alcohol, smoking, body mass index, or meat intake. Any further studies should report analyses stratified by other risk factors to better be able to rule out residual confounding.

Although publication bias can be a problem in meta-analyses of published literature we found no evidence of such bias in this analysis. In addition, the few studies that were excluded from the dose-response analysis of dietary fibre are unlikely to have altered the results because the results from the analyses of high versus low intake were similar when we repeated the analyses with the same dataset as in the dose-response analysis.

Accurate assessment of dietary fibre intake and other food constituents is a challenge. The definition of dietary fibre may differ between studies and may contribute to heterogeneity in the results. Some studies used the Englyst definition of fibre, which distinguishes non-starch polysaccharides from starch, whereas other studies calculated fibre intake using the Association of Official Analytical Chemists method, which includes some starch as dietary fibre. The summary relative risks were generally similar, however, no matter which method was used, and there was no evidence of heterogeneity between subgroups when stratified by the method used to calculate fibre intake.

Most studies carried out to date have used food frequency questionnaires to assess dietary intake. Concern is, however, increasing that measurement errors associated with the use of food frequency questionnaires may obscure associations between dietary intake and risk of chronic disease.${ }^{64} \mathrm{Few}$ studies have reported results corrected for measurement errors. In the EPIC study the relative risk of colorectal cancer was 0.75 (95\% confidence interval 0.59 to 0.95 ) for the highest compared with lowest fifths of fibre intake, and after calibration with more detailed data the relative risk was 0.58 (0.41 to 0.85$).{ }^{19}$ In the Pooling Project of Prospective Studies the adjusted relative risk for less than $10 \mathrm{~g} /$ day compared with $10 \mathrm{~g}$ /day or more was 1.22 (1.10 to 1.35 ), but this increased to 2.16 (1.12 to 4.16 ) after correction for measurement error. ${ }^{31}$ In a pooled analysis of seven UK based cohort studies, a stronger association was observed when food diaries were used to assess dietary fibre intake; an odds ratio of 0.66 (95\% confidence interval 0.45 to 0.96 ) for the highest versus lowest fifths of fibre density compared with 0.88 ( 0.57 to 1.36$)$ when food frequency questionnaires were 
used to measure dietary intake. ${ }^{65}$ The latter was of similar size to our summary estimate for the highest versus lowest intake (summary relative risk $0.88,95 \%$ confidence interval 0.82 to 0.94). The results using food diaries were further strengthened when corrected for measurement errors: odds ratio $0.68(95 \%$ confidence interval 0.48 to 0.96 ) for a $0.7 \mathrm{~g} / \mathrm{MJ}$ increase in fibre intake (uncorrected odds ratio $0.83,95 \%$ confidence interval 0.70 to 0.97$).{ }^{65}$ The results from these studies suggest that our results for dietary fibre and risk of colorectal cancer are likely to be conservative estimates of the true underlying risk and that any further studies should incorporate correction for measurement error in the analyses.

\section{Strengths of the study}

Our meta-analysis also has several strengths. Because we based our analysis on prospective studies, our findings are unlikely to be explained by recall bias and selection bias. Our meta-analysis included a large number of studies and more than 14500 cases, and almost two million participants in the dietary fibre analysis. Thus we had adequate statistical power to clarify the shape of the dose-response relation between dietary fibre intake and risk of colorectal cancer and to detect moderate reductions in risk. We also carried out sensitivity analyses to investigate whether any particular study explained the results, but the findings were generally robust. We quantified the association between intake of dietary fibre and whole grain and risk of colorectal cancer by carrying out linear and non-linear dose-response analyses.

\section{Mechanisms}

A protective effect of dietary fibre and whole grain consumption on risk of colorectal cancer is biologically plausible. Whole grain foods are important sources of dietary fibre and may decrease the risk of colorectal cancer by increasing stool bulk, diluting faecal carcinogens, and decreasing transit time, thus reducing the contact between carcinogens and the lining of the colorectum. ${ }^{7}$ In addition, bacterial fermentation of fibre results in the production of short chain fatty acids, which may have protective effects against colorectal cancer. ${ }^{66}$ Other components of whole grains may also protect against colorectal cancer, including antioxidants, vitamins, trace minerals, phytate, phenolic acids, lignans, and phytoestrogens ${ }^{66-68}$ Whole grains have a high content of folate and magnesium, which have been associated with a reduced risk of colorectal cancer. ${ }^{69-71}$ Higher intakes of dietary fibre and whole grain also protect against weight gain ${ }^{72} 73$ and type 2 diabetes, ${ }^{74} 75$ and it is possible that part of the potential effect of fibre intake is mediated through improved weight control and reduced insulin resistance, although these may not be the main mechanisms. However, the results persisted in studies that adjusted for both folate and body mass index, suggesting an association independent of folate and body mass index.

\section{Conclusions and policy implications}

Our results indicate a $10 \%$ reduction in risk of colorectal cancer for each $10 \mathrm{~g} /$ day intake of total dietary fibre and cereal fibre and a about a $20 \%$ reduction for each three servings ( $90 \mathrm{~g} /$ day) of whole grain daily, and further reductions with higher intake. These findings thus have important public health implications. Our results provide further support for public health recommendations to increase the intake of dietary fibre in the prevention of colorectal cancer. However, they suggest a particular benefit of increasing cereal fibre and whole grain intake. Increasing the intake of dietary fibre and whole grains is also likely to reduce the risk of cardiovascular disease, ${ }^{76-78}$ type 2 diabetes, ${ }^{74} 75$ overweight and obesity, ${ }^{72}{ }^{73}$ and possibly overall mortality, ${ }^{76} 78$ thus there are several health benefits by increasing fibre intake and replacing refined grains with whole grains.

In summary, our meta-analysis suggests that a high intake of dietary fibre, particularly from cereal and whole grains, is associated with a reduced risk of colorectal cancer. Further studies should report more detailed results, including those for subtypes of fibre, stratify the results by subsites within the colorectum, and stratify the results by other risk factors to be able to rule out residual confounding. Further assessment of the impact of measurement errors on the risk estimates is also warranted.

We thank the systematic literature review team at Wageningen University for their contributions to the colorectal cancer database.

Contributors: The systematic literature review team at Wageningen University carried out the search, and selected and extracted data up to the end of December 2005. RV developed and managed the database for the Continuous Update Project. RL and DSMC did the updated literature search. RL, DSMC, and DA did the updated data extraction. DA and DSMC selected the studies and carried out the statistical analyses. DCG was statistical adviser and contributed to the statistical analyses. All authors revised the manuscript. EK was principal investigator of the Systematic Literature Reviews at Wageningen University. TN is principal investigator of the Continuous Update Project and wrote the protocol and implemented the study. DA wrote the first draft of the original manuscript. All authors had full access to all of the data in the study and prepared the manuscript. DA is guarantor. The sponsor of this study had no role in the decisions about the design and conduct of the study; collection, management, analysis, or interpretation of the data; or the preparation, review, or approval of the manuscript. The views expressed in this review are the opinions of the authors. They may not represent the views of the World Cancer Research Fund International/American Institute for Cancer Research and may differ from those in future updates of the evidence related to food, nutrition, physical activity, and cancer risk.

Funding: This work was funded by the World Cancer Research Fund (grant No 2007/SP01) as part of the Continuous Update Project.

Competing interests: All authors have completed the ICMJE uniform disclosure form at www.icmje.org/coi_disclosure.pdf (available on request from the corresponding author) and declare: no support from any organisation for the submitted work; no financial relationships with any organisations that might have an interest in the submitted work in the previous three years; and no other relationships or activities that could appear to have influenced the submitted work.

Ethical approval: Not required.

Data sharing: No additional data available.

1 Ferlay J, Shin HR, Bray F, Forman D, Mathers C, Parkin DM. Estimates of worldwide burden of cancer in 2008: GLOBOCAN 2008. Int J Cancer 2010;127:2893-917.

2 Armstrong B, Doll R. Environmental factors and cancer incidence and mortality in different countries, with special reference to dietary practices. Int J Cancer 1975;15:617-31.

3 Kolonel LN. Cancer patterns of four ethnic groups in Hawaii. J Natl Cancer Inst 1980;65:1127-39.

4 Kono S. Secular trend of colon cancer incidence and mortality in relation to fat and meat intake in Japan. Eur J Cancer Prev 2004;13:127-32.

5 World Cancer Research Fund/American Institute for Cancer Research. Food, nutrition, physical activity and the prevention of cancer: a global perspective. AICR, 2007.

6 Burkitt DP. Epidemiology of cancer of the colon and rectum. Cancer 1971;28:3-13.

7 Lipkin M, Reddy B, Newmark H, Lamprecht SA. Dietary factors in human colorectal cancer. Annu Rev Nutr 1999;19:545-86.

8 Bingham SA, Norat T, Moskal A, Ferrari P, Slimani N, Clavel-Chapelon F, et al. Is the association with fiber from foods in colorectal cancer confounded by folate intake? Cancer Epidemiol Biomarkers Prev 2005;14:1552-6.

9 Howe GR, Benito E, Castelleto R, Cornee J, Esteve J, Gallagher RP, et al. Dietary intake of fiber and decreased risk of cancers of the colon and rectum: evidence from the combined analysis of 13 case-control studies. J Natl Cancer Inst 1992;84:1887-96.

10 Trock B, Lanza E, Greenwald P. Dietary fiber, vegetables, and colon cancer: critical review and meta-analyses of the epidemiologic evidence. J Natl Cancer Inst 1990;82:650-61. 


\section{What is already known on this topic}

Colorectal cancer is the third most common cancer worldwide, with 1.2 million new cases annually

Intake of dietary fibre and whole grains has been established as protective against cardiovascular disease, but the association with colorectal cancer is not convincing

It is unclear whether only specific types of fibre or sources of fibre are associated with the risk of colorectal cancer

\section{What this study adds}

Intakes of dietary fibre, cereal fibre, and whole grains are associated with linear decreases in the risk of colorectal cancer

Evidence of an association between intake of fruit, vegetable, or legume fibre and risk of colorectal cancer was lacking Intake of dietary fibre, particularly cereal fibre and whole grains, was associated with a small reduction in the risk of colorectal cancer

11 Wu AH, Paganini-Hill A, Ross RK, Henderson BE. Alcohol, physical activity and other risk factors for colorectal cancer: a prospective study. Br J Cancer 1987;55:687-94.

12 Heilbrun LK, Nomura A, Hankin JH, Stemmermann GN. Diet and colorectal cancer with special reference to fiber intake. Int J Cancer 1989;44:1-6.

13 Steinmetz KA, Kushi LH, Bostick RM, Folsom AR, Potter JD. Vegetables, fruit, and colon cancer in the lowa Women's Health Study. Am J Epidemiol 1994;139:1-15.

14 Gaard M, Tretli S, Loken EB. Dietary factors and risk of colon cancer: a prospective study of 50,535 young Norwegian men and women. Eur J Cancer Prev 1996;5:445-54.

15 Kato I, Akhmedkhanov A, Koenig K, Toniolo PG, Shore RE, Riboli E. Prospective study of diet and female colorectal cancer: the New York University Women's Health Study. Nutr Cancer 1997;28:276-81.

16 Pietinen P, Malila N, Virtanen M, Hartman TJ, Tangrea JA, Albanes D, et al. Diet and risk of colorectal cancer in a cohort of Finnish men. Cancer Causes Control 1999;10:387-96.

17 Terry P, Giovannucci E, Michels KB, Bergkvist L, Hansen H, Holmberg L, et al. Fruit, vegetables, dietary fiber, and risk of colorectal cancer. J Natl Cancer Inst 2001;93:525-33.

18 Mai V, Flood A, Peters U, Lacey JV Jr, Schairer C, Schatzkin A. Dietary fibre and risk of colorectal cancer in the Breast Cancer Detection Demonstration Project (BCDDP) follow-up cohort. Int J Epidemiol 2003;32:234-9.

19 Bingham SA, Day NE, Luben R, Ferrari P, Slimani N, Norat T, et al. Dietary fibre in food and protection against colorectal cancer in the European Prospective Investigation into Cancer and Nutrition (EPIC): an observational study. Lancet 2003;361:1496-501.

20 Sanjoaquin MA, Appleby PN, Thorogood M, Mann JI, Key TJ. Nutrition, lifestyle and colorectal cancer incidence: a prospective investigation of 10998 vegetarians and non-vegetarians in the United Kingdom. Br J Cancer 2004;90:118-21.

21 Michels KB, Fuchs CS, Giovannucci E, Colditz GA, Hunter DJ, Stampfer MJ, et al. Fiber intake and incidence of colorectal cancer among 76,947 women and 47,279 men. Cancer Epidemiol Biomarkers Prev 2005;14:842-9.

22 Lin J, Zhang SM, Cook NR, Rexrode KM, Liu S, Manson JE, et al. Dietary intakes of fruit, vegetables, and fiber, and risk of colorectal cancer in a prospective cohort of women (United States). Cancer Causes Control 2005;16:225-33.

23 Shin A, Li H, Shu XO, Yang G, Gao YT, Zheng W. Dietary intake of calcium, fiber and other micronutrients in relation to colorectal cancer risk: results from the Shanghai Women's Health Study. Int J Cancer 2006;119:2938-42.

24 Otani T, Iwasaki M, Ishihara J, Sasazuki S, Inoue M, Tsugane S. Dietary fiber intake and subsequent risk of colorectal cancer: the Japan Public Health Center-based prospective study. Int J Cancer 2006;119:1475-80.

25 McCarl M, Harnack L, Limburg PJ, Anderson KE, Folsom AR. Incidence of colorectal cancer in relation to glycemic index and load in a cohort of women. Cancer Epidemiol Biomarkers Prev 2006;15:892-6.

26 Wakai K, Date C, Fukui M, Tamakoshi K, Watanabe Y, Hayakawa N, et al. Dietary fiber and risk of colorectal cancer in the Japan collaborative cohort study. Cancer Epidemiol Biomarkers Prev 2007;16:668-75.

27 Schatzkin A, Mouw T, Park Y, Subar AF, Kipnis V, Hollenbeck A, et al. Dietary fiber and whole-grain consumption in relation to colorectal cancer in the NIH-AARP Diet and Health Study. Am J Clin Nutr 2007:85:1353-60.

28 Nomura AM, Hankin JH, Henderson BE, Wilkens LR, Murphy SP, Pike MC, et al. Dietary fiber and colorectal cancer risk: the multiethnic cohort study. Cancer Causes Control 2007; 18:753-64.

29 Kabat GC, Shikany JM, Beresford SA, Caan B, Neuhouser ML, Tinker LF, et al. Dietary carbohydrate, glycemic index, and glycemic load in relation to colorectal cancer risk in the Women's Health Initiative. Cancer Causes Control 2008;19:1291-8.

30 Butler LM, Wang R, Koh WP, Yu MC. Prospective study of dietary patterns and colorectal cancer among Singapore Chinese. Br J Cancer 2008;99:1511-6.

31 Park Y, Hunter DJ, Spiegelman D, Bergkvist L, Berrino F, van den Brandt PA, et al. Dietary fiber intake and risk of colorectal cancer: a pooled analysis of prospective cohort studies. JAMA 2005;294:2849-57.

32 Slavin JL, Martini MC, Jacobs DR Jr, Marquart L. Plausible mechanisms for the protectiveness of whole grains. Am J Clin Nutr 1999;70:S459-63.

33 Jacobs DR Jr, Marquart L, Slavin J, Kushi LH. Whole-grain intake and cancer: an expanded review and meta-analysis. Nutr Cancer 1998;30:85-96.

34 Appleby PN, Key TJ, Burr ML, Thorogood M. Mortality and fresh fruit consumption. IARC Sci Publ 2002;156:131-3.

35 Larsson SC, Giovannucci E, Bergkvist L, Wolk A. Whole grain consumption and risk of colorectal cancer: a population-based cohort of 60,000 women. Br J Cancer 2005:92:1803-7.

36 McCullough ML, Robertson AS, Chao A, Jacobs EJ, Stampfer MJ, Jacobs DR, et al. A prospective study of whole grains, fruits, vegetables and colon cancer risk. Cancer Causes Control 2003;14:959-70.

37 Wu K, Hu FB, Fuchs C, Rimm EB, Willett WC, Giovannucci E. Dietary patterns and risk of colon cancer and adenoma in a cohort of men (United States). Cancer Causes Control 2004; 15:853-62.

38 Egeberg R, Olsen A, Loft S, Christensen J, Johnsen NF, Overvad K, et al. Intake of wholegrain products and risk of colorectal cancers in the Diet, Cancer and Health cohort study. Br J Cancer 2010;103:730-4.

39 Fung TT, Hu FB, Wu K, Chiuve SE, Fuchs CS, Giovannucci E. The Mediterranean and Dietary Approaches to Stop Hypertension (DASH) diets and colorectal cancer. Am J Clin Nutr 2010;92:1429-35.
40 Stroup DF, Berlin JA, Morton SC, Olkin I, Williamson GD, Rennie D, et al. Meta-analysis of observational studies in epidemiology: a proposal for reporting. Meta-analysis $\mathrm{Of}$ Observational Studies in Epidemiology (MOOSE) group. JAMA 2000;283:2008-12.

41 Haas P, Machado MJ, Anton AA, Silva AS, De Francisco A. Effectiveness of whole grain consumption in the prevention of colorectal cancer: Meta-analysis of cohort studies. Int $J$ Food Sci Nutr 2009;Mar 21:1-13. [Epub ahead of print.]

42 Bostick RM, Potter JD, Sellers TA, McKenzie DR, Kushi LH, Folsom AR. Relation of calcium, vitamin D, and dairy food intake to incidence of colon cancer among older women. The lowa Women's Health Study. Am J Epidemiol 1993;137:1302-17.

43 Glynn SA, Albanes D, Pietinen P, Brown CC, Rautalahti M, Tangrea JA, et al. Alcoho consumption and risk of colorectal cancer in a cohort of Finnish men. Cancer Causes Control 1996;7:214-23.

44 Tangrea J, Helzlsouer K, Pietinen P, Taylor P, Hollis B, Virtamo J, et al. Serum levels of vitamin $\mathrm{D}$ metabolites and the subsequent risk of colon and rectal cancer in Finnish men. Cancer Causes Control 1997;8:615-25.

45 Colbert LH, Hartman TJ, Malila N, Limburg PJ, Pietinen P, Virtamo J, et al. Physical activity in relation to cancer of the colon and rectum in a cohort of male smokers. Cancer Epidemiol Biomarkers Prev 2001;10:265-8

46 Konings EJ, Goldbohm RA, Brants HA, Saris WH, van den Brandt PA. Intake of dietary folate vitamers and risk of colorectal carcinoma: results from The Netherlands Cohort Study. Cancer 2002;95:1421-33.

47 Wong HL, Seow A, Arakawa K, Lee HP, Yu MC, Ingles SA. Vitamin D receptor start codon polymorphism and colorectal cancer risk: effect modification by dietary calcium and fat in Singapore Chinese. Carcinogenesis 2003;24:1091-5.

48 Koh WP, Yuan JM, van den BD, Lee HP, Yu MC. Interaction between cyclooxygenase-2 gene polymorphism and dietary $n-6$ polyunsaturated fatty acids on colon cancer risk: the Singapore Chinese Health Study. Br J Cancer 2004:90:1760-4.

49 Willett WC, Stampfer MJ, Colditz GA, Rosner BA, Speizer FE. Relation of meat, fat, and fiber intake to the risk of colon cancer in a prospective study among women. $N$ Engl $J$ Med 1990;323:1664-72.

50 Giovannucci E, Rimm EB, Stampfer MJ, Colditz GA, Ascherio A, Willett WC. Intake of fat, meat, and fiber in relation to risk of colon cancer in men. Cancer Res 1994;54:2390-7.

51 Sellers TA, Bazyk AE, Bostick RM, Kushi LH, Olson JE, Anderson KE, et al. Diet and risk of colon cancer in a large prospective study of older women: an analysis stratified on family history (lowa, United States). Cancer Causes Control 1998;9:357-67.

52 Fuchs CS, Giovannucci EL, Colditz GA, Hunter DJ, Stampfer MJ, Rosner B, et al. Dietary fiber and the risk of colorectal cancer and adenoma in women. $N$ Engl $\mathrm{J}$ Med 1999;340:169-76.

53 Higginbotham S, Zhang ZF, Lee IM, Cook NR, Giovannucci E, Buring JE, et al. Dietary glycemic load and risk of colorectal cancer in the Women's Health Study. J Natl Cancer Inst 2004;96:229-33.

54 Norat T, Bingham S, Ferrari P, Slimani N, Jenab M, Mazuir M, et al. Meat, fish, and colorectal cancer risk: the European Prospective Investigation into cancer and nutrition. J Natl Cancer Inst 2005;97:906-16.

55 Greenland S, Longnecker MP. Methods for trend estimation from summarized dose-response data, with applications to meta-analysis. Am J Epidemiol 1992;135:1301-9.

56 Royston P. A strategy for modelling the effect of a continuous covariate in medicine and epidemiology. Stat Med 2000;19:1831-47.

57 Bagnardi V, Zambon A, Quatto P, Corrao G. Flexible meta-regression functions for modeling aggregate dose-response data, with an application to alcohol and mortality. $A m$ J Epidemiol 2004;159:1077-86.

58 Higgins JP, Thompson SG. Quantifying heterogeneity in a meta-analysis. Stat Med 2002:21:1539-58.

59 Egger M, Davey SG, Schneider M, Minder C. Bias in meta-analysis detected by a simple, graphical test. BMJ 1997;315:629-34.

60 Begg CB, Mazumdar M. Operating characteristics of a rank correlation test for publication bias. Biometrics 1994;50:1088-101.

61 Aune D, Lau R, Chan DS, Vieira R, Greenwood DC, Kampman E, et al. Nonlinear reduction in risk for colorectal cancer by fruit and vegetable intake based on meta-analysis of prospective studies. Gastroenterology 2011;141:106-18

62 Beresford SA, Johnson KC, Ritenbaugh C, Lasser NL, Snetselaar LG, Black HR, et al. Low-fat dietary pattern and risk of colorectal cancer: the Women's Health Initiative randomized controlled dietary modification trial. JAMA 2006;295:643-54.

63 Sun Q, Spiegelman D, van Dam RM, Holmes MD, Malik VS, Willett WC, et al. White rice, brown rice, and risk of type 2 diabetes in US men and women. Arch Intern Med 2010;170:961-9.

64 Kipnis V, Subar AF, Midthune D, Freedman LS, Ballard-Barbash R, Troiano RP, et al. Structure of dietary measurement error: results of the OPEN biomarker study. Am J Epidemiol 2003;158:14-21.

65 Dahm CC, Keogh RH, Spencer EA, Greenwood DC, Key TJ, Fentiman IS, et al. Dietary fiber and colorectal cancer risk: a nested case-control study using food diaries. J Natl Cancer Inst 2010;102:614-26.

66 Slavin JL. Mechanisms for the impact of whole grain foods on cancer risk. J Am Coll Nutr 2000;19:S300-7.

67 Cotterchio M, Boucher BA, Manno M, Gallinger S, Okey A, Harper P. Dietary phytoestrogen intake is associated with reduced colorectal cancer risk. J Nutr 2006;136:3046-53. 
68 Webb AL, McCullough ML. Dietary lignans: potential role in cancer prevention. Nutr Cancer 2005;51:117-31.

69 Sanjoaquin MA, Allen N, Couto E, Roddam AW, Key TJ. Folate intake and colorectal cancer risk: a meta-analytical approach. Int J Cancer 2005;113:825-8.

70 Folsom AR, Hong CP. Magnesium intake and reduced risk of colon cancer in a prospective study of women. Am J Epidemiol 2006;163:232-5.

71 Larsson SC, Bergkvist L, Wolk A. Magnesium intake in relation to risk of colorectal cancer in women. JAMA 2005;293:86-9.

72 Bazzano LA, Song Y, Bubes V, Good CK, Manson JE, Liu S. Dietary intake of whole and refined grain breakfast cereals and weight gain in men. Obes Res 2005;13:1952-60.

73 Liu S, Willett WC, Manson JE, Hu FB, Rosner B, Colditz G. Relation between changes in intakes of dietary fiber and grain products and changes in weight and development of obesity among middle-aged women. Am J Clin Nutr 2003;78:920-7.

74 De Munter JS, Hu FB, Spiegelman D, Franz M, van Dam RM. Whole grain, bran, and germ intake and risk of type 2 diabetes: a prospective cohort study and systematic review. LLOS Med 2007;4:e261.

75 Schulze MB, Schulz M, Heidemann C, Schienkiewitz A, Hoffmann K, Boeing H. Fiber and magnesium intake and incidence of type 2 diabetes: a prospective study and meta-analysis. Arch Intern Med 2007;167:956-65.
76 Jacobs DR Jr, Andersen LF, Blomhoff R. Whole-grain consumption is associated with a reduced risk of noncardiovascular, noncancer death attributed to inflammatory diseases in the lowa Women's Health Study. Am J Clin Nutr 2007;85:1606-14.

77 Mente A, de Koning L, Shannon HS, Anand SS. A systematic review of the evidence supporting a causal link between dietary factors and coronary heart disease. Arch Inter Med 2009;169:659-69.

78 Park Y, Subar AF, Hollenbeck A, Schatzkin A. Dietary fiber intake and mortality in the NIH-AARP Diet and Health Study. Arch Intern Med 2011:171:1061-8.

Accepted: 21 September 2011

Cite this as: BMJ 2011;343:d6617

This is an open-access article distributed under the terms of the Creative Commons Attribution Non-commercial License, which permits use, distribution, and reproduction in any medium, provided the original work is properly cited, the use is non commercial and is otherwise in compliance with the license. See: http://creativecommons.org/licenses/bync/2.0/ and http://creativecommons.org/licenses/by-nc/2.0/legalcode. 


\section{Tables}

\begin{tabular}{|c|c|c|c|c|c|c|c|c|}
\hline $\begin{array}{l}\text { Study, } \\
\text { country }\end{array}$ & Study name & $\begin{array}{l}\text { Follow-up } \\
\text { period }\end{array}$ & $\begin{array}{l}\text { Study size, } \\
\text { sex, age, No } \\
\text { of cases* }\end{array}$ & $\begin{array}{c}\text { Diet } \\
\text { assessment, } \\
\text { No of items, } \\
\text { fibre definition }\end{array}$ & Exposure & Quantity & $\begin{array}{l}\text { Relative risk (95\% } \\
\text { Cl) }\end{array}$ & $\begin{array}{l}\text { Adjustment for } \\
\text { confounders }\end{array}$ \\
\hline $\begin{array}{l}\text { Kabat } 2008^{29} \text {, } \\
\text { USA }\end{array}$ & $\begin{array}{l}\text { Women's Health } \\
\text { Initiative }\end{array}$ & $\begin{array}{l}\text { 1993-8, } 7.9 \\
\text { years }\end{array}$ & $\begin{array}{l}158800 \\
\text { women, age } \\
50-79,1476 \\
\text { cases }\end{array}$ & $\begin{array}{l}\text { Validated food } \\
\text { frequency } \\
\text { questionnaire, } \\
122 \text { food items, } \\
\text { NA }\end{array}$ & Total fibre & $\geq 21.2 v<9.9 \mathrm{~g} /$ day & $1.06(0.67$ to 1.70$)$ & $\begin{array}{l}\text { Age, education, daily } \\
\text { cigarette } \\
\text { consumption, body } \\
\text { mass index, height, } \\
\text { HRT, diabetes } \\
\text { mellitus, family } \\
\text { history of colorectal } \\
\text { cancer, physical } \\
\text { activity, } \\
\text { observational study } \\
\text { participant, energy, } \\
\text { dietary calcium }\end{array}$ \\
\hline $\begin{array}{l}\text { Butler } 2008^{30} \text {, } \\
\text { Singapore }\end{array}$ & $\begin{array}{l}\text { Singapore } \\
\text { Chinese Health } \\
\text { Study }\end{array}$ & $\begin{array}{l}1993-2005 \\
9.8 \text { years }\end{array}$ & $\begin{array}{l}61321 \text { men } \\
\text { and women, } \\
\text { age } 45-74,961 \\
\text { cases }\end{array}$ & $\begin{array}{l}\text { Validated food } \\
\text { frequency } \\
\text { questionnaire, } \\
165 \text { food items, } \\
\text { NA }\end{array}$ & Dietary fibre & Fourths: $4 v 1$ & $0.98(0.81$ to 1.19$)$ & $\begin{array}{l}\text { Age, sex, dialect } \\
\text { group, interview } \\
\text { year, diabetes } \\
\text { mellitus, smoking, } \\
\text { body mass index, } \\
\text { alcohol, education, } \\
\text { physical activity, } \\
\text { family history of } \\
\text { colorectal cancer, } \\
\text { energy }\end{array}$ \\
\hline \multirow[t]{10}{*}{$\begin{array}{l}\text { Nomura } \\
2007^{28}, \text { USA }\end{array}$} & \multirow[t]{10}{*}{$\begin{array}{l}\text { Multiethnic } \\
\text { Cohort Study }\end{array}$} & \multirow[t]{10}{*}{$\begin{array}{l}1993-2001 \\
7.3 \text { years }\end{array}$} & \multirow{10}{*}{$\begin{array}{l}85903 \text { men } \\
\text { and } 105108 \\
\text { women, age } \\
45-75, \\
1138 / 972 \\
\text { cases }\end{array}$} & \multirow{10}{*}{$\begin{array}{l}\text { Validated food } \\
\text { frequency } \\
\text { questionnaire, } \\
180 \text { food items, } \\
\text { AOAC method }\end{array}$} & $\begin{array}{l}\text { Dietary fibre, } \\
\text { men }\end{array}$ & $\begin{array}{c}16.5 \vee 6.1 \mathrm{~g} / 1000 \\
\mathrm{kcal} / \text { day }\end{array}$ & 0.62 (0.48 to 0.79$)$ & \multirow{10}{*}{$\begin{array}{l}\text { Age, ethnicity, time } \\
\text { since cohort entry, } \\
\text { family history of } \\
\text { colorectal cancer, } \\
\text { history of colorecta } \\
\text { polyps, pack years } \\
\text { of cigarette } \\
\text { smoking, body } \\
\text { mass index, hours } \\
\text { of vigorous activity } \\
\text { aspirin use, } \\
\text { multivitamin use, } \\
\text { HRT, alcohol, red } \\
\text { meat, folate, vitamir } \\
\text { D, calcium, energy }\end{array}$} \\
\hline & & & & & Fruit fibre, men & $\begin{array}{c}12.6 \text { v } 0.9 \mathrm{~g} / 1000 \\
\mathrm{kcal} / \text { day }\end{array}$ & 0.78 (0.63 to 0.97$)$ & \\
\hline & & & & & $\begin{array}{l}\text { Vegetable fibre, } \\
\text { men }\end{array}$ & $\begin{array}{c}18.4 \text { v } 3.0 \mathrm{~g} / 1000 \\
\mathrm{kcal} / \text { day }\end{array}$ & $0.78(0.62$ to 0.97$)$ & \\
\hline & & & & & Grain fibre, men & $\begin{array}{c}15.6 \text { v } 2.8 \mathrm{~g} / 1000 \\
\mathrm{kcal} / \text { day }\end{array}$ & 0.86 (0.69 to 1.07$)$ & \\
\hline & & & & & $\begin{array}{l}\text { Legume fibre, } \\
\text { men }\end{array}$ & $\begin{array}{c}7.6 \vee 0.3 \mathrm{~g} / 1000 \\
\mathrm{kcal} / \mathrm{day}\end{array}$ & $0.87(0.68$ to 1.10$)$ & \\
\hline & & & & & $\begin{array}{l}\text { Dietary fibre, } \\
\text { women }\end{array}$ & $\begin{array}{c}18.6 \vee 7.5 \mathrm{~g} / 1000 \\
\mathrm{kcal} / \text { day }\end{array}$ & $0.88(0.67$ to 1.14$)$ & \\
\hline & & & & & $\begin{array}{l}\text { Fruit fibre, } \\
\text { women }\end{array}$ & $\begin{array}{c}14.0 \text { v } 1.2 \mathrm{~g} / 1000 \\
\mathrm{kcal} / \text { day }\end{array}$ & $0.82(0.64$ to 1.05$)$ & \\
\hline & & & & & $\begin{array}{l}\text { Vegetable fibre, } \\
\text { women }\end{array}$ & $\begin{array}{c}17.2 \text { v } 3.0 \mathrm{~g} / 1000 \\
\mathrm{kcal} / \text { day }\end{array}$ & $0.95(0.75$ to 1.20$)$ & \\
\hline & & & & & $\begin{array}{l}\text { Grain fibre, } \\
\text { women }\end{array}$ & $\begin{array}{c}14.0 \vee 2.4 \mathrm{~g} / 1000 \\
\mathrm{kcal} / \text { day }\end{array}$ & $1.00(0.78$ to 1.27$)$ & \\
\hline & & & & & $\begin{array}{l}\text { Legume fibre, } \\
\text { women }\end{array}$ & $\begin{array}{c}5.8 \vee 0.2 \mathrm{~g} / 1000 \\
\mathrm{kcal} / \text { day }\end{array}$ & $1.16(0.90$ to 1.49$)$ & \\
\hline \multirow[t]{5}{*}{$\begin{array}{l}\text { Schatzkin } \\
2007^{27}, \text { USA }\end{array}$} & \multirow{5}{*}{$\begin{array}{l}\text { NIH-AARP Diet } \\
\text { and Health } \\
\text { Study }\end{array}$} & \multirow[t]{5}{*}{$\begin{array}{l}1995-2000 \\
4.5 \text { years }\end{array}$} & \multirow{5}{*}{$\begin{array}{l}291988 \text { men } \\
\text { and } 197623 \\
\text { women, age } \\
50-71,2974 \\
\text { cases }\end{array}$} & \multirow{5}{*}{$\begin{array}{l}\text { Validated food } \\
\text { frequency } \\
\text { questionnaire, } \\
124 \text { food items, } \\
\text { AOAC method }\end{array}$} & Dietary fibre & $\begin{array}{c}15.9 \text { v } 6.6 \mathrm{~g} / 1000 \\
\mathrm{kcal} / \text { day }\end{array}$ & $0.99(0.85$ to 1.15$)$ & \multirow{5}{*}{$\begin{array}{l}\text { Age, sex, physical } \\
\text { activity, smoking, } \\
\text { HRT (women), red } \\
\text { meat, dietary } \\
\text { calcium, dietary } \\
\text { folate, energy }\end{array}$} \\
\hline & & & & & Grain fibre & $\begin{array}{c}5.7 \vee 1.7 \mathrm{~g} / 1000 \\
\mathrm{kcal} / \text { day }\end{array}$ & 0.86 (0.76 to 0.98$)$ & \\
\hline & & & & & Fruit fibre & $\begin{array}{c}4.8 \vee 0.5 \mathrm{~g} / 1000 \\
\mathrm{kcal} / \text { day }\end{array}$ & $1.08(0.95$ to 1.23$)$ & \\
\hline & & & & & Vegetable fibre & $\begin{array}{c}6.0 \vee 1.7 \mathrm{~g} / 1000 \\
\mathrm{kcal} / \text { day }\end{array}$ & 1.01 (0.89 to 1.15$)$ & \\
\hline & & & & & Bean fibre & $\begin{array}{c}2.3 v 0.2 \mathrm{~g} / 1000 \\
\mathrm{kcal} / \mathrm{day}\end{array}$ & $0.93(0.83$ to 1.04$)$ & \\
\hline
\end{tabular}


Table 1 (continued)

\begin{tabular}{|c|c|c|c|c|c|c|c|c|}
\hline $\begin{array}{l}\text { Study, } \\
\text { country }\end{array}$ & Study name & $\begin{array}{l}\text { Follow-up } \\
\text { period }\end{array}$ & $\begin{array}{l}\text { Study size, } \\
\text { sex, age, No } \\
\text { of cases* }\end{array}$ & $\begin{array}{c}\text { Diet } \\
\text { assessment, } \\
\text { No of items, } \\
\text { fibre definition }\end{array}$ & Exposure & Quantity & $\begin{array}{l}\text { Relative risk (95\% } \\
\text { CI) }\end{array}$ & $\begin{array}{l}\text { Adjustment for } \\
\text { confounders }\end{array}$ \\
\hline $\begin{array}{l}\text { Wakai } \\
2007^{26} \\
\text { Japan }\end{array}$ & $\begin{array}{l}\text { Japan } \\
\text { Collaborative } \\
\text { Cohort Study }\end{array}$ & $\begin{array}{l}1988-97,7.6 \\
\text { years }\end{array}$ & $\begin{array}{l}43115 \text { men } \\
\text { and women, } \\
\text { age } 40-79,443 \\
\text { cases }\end{array}$ & $\begin{array}{l}\text { Validated food } \\
\text { frequency } \\
\text { questionnaire, } \\
40 \text { food items, } \\
\text { AOAC method }\end{array}$ & $\begin{array}{l}\text { Total dietary } \\
\text { fibre }\end{array}$ & $\begin{array}{c}13.4 / 13.4 v 6.7 / 7.4 \\
\text { g/d men and women }\end{array}$ & $0.73(0.51$ to 1.03$)$ & $\begin{array}{l}\text { Age, sex, area, } \\
\text { education, family } \\
\text { history of colorectal } \\
\text { cancer, alcohol, } \\
\text { smoking, body mass } \\
\text { index, walking, } \\
\text { exercise, sedentary } \\
\text { work, beef/pork, } \\
\text { energy, folate, } \\
\text { calcium, vitamin D }\end{array}$ \\
\hline $\begin{array}{l}\text { McCarl } \\
2006^{25}, \text { USA }\end{array}$ & $\begin{array}{l}\text { lowa Women's } \\
\text { Health Study }\end{array}$ & $\begin{array}{l}1986-2001 \\
15 \text { years }\end{array}$ & $\begin{array}{l}35197 \text { women, } \\
\text { age } 55-69,954 \\
\text { cases }\end{array}$ & $\begin{array}{l}\text { Validated food } \\
\text { frequency } \\
\text { questionnaire, } \\
131 \text { food items, } \\
\text { NA }\end{array}$ & Fibre & $\geq 25.4 v \leq 13.2 \mathrm{~g} / \mathrm{day}$ & 0.75 (0.61 to 0.92$)$ & Age \\
\hline $\begin{array}{l}\text { Shin } 2006^{23} \text {, } \\
\text { China }\end{array}$ & $\begin{array}{l}\text { Shanghai } \\
\text { Women's Health } \\
\text { Study }\end{array}$ & $\begin{array}{l}1997-2004, \\
5.74 \text { years }\end{array}$ & $\begin{array}{l}73314 \text { women, } \\
\text { age } 40-70,283 \\
\text { cases }\end{array}$ & $\begin{array}{l}\text { Validated food } \\
\text { frequency } \\
\text { questionnaire, } \\
77 \text { food items, } \\
\text { NA }\end{array}$ & Fibre & Fifths: $5 v 1$ & $1.1(0.6$ to 1.8$)$ & $\begin{array}{l}\text { Age, menopausal } \\
\text { status, education, } \\
\text { smoking, alcohol, } \\
\text { exercise, family } \\
\text { history of colorectal } \\
\text { cancer, energy, } \\
\text { vitamin supplements }\end{array}$ \\
\hline \multirow{2}{*}{$\begin{array}{l}\text { Otani } \\
2006^{24} \\
\text { Japan }\end{array}$} & \multirow{2}{*}{$\begin{array}{l}\text { Japan Public } \\
\text { Health } \\
\text { Center-based } \\
\text { Prospective } \\
\text { Study }\end{array}$} & \multirow{2}{*}{$\begin{array}{l}\text { Cohort 1: } \\
\text { 1995-2002; } \\
\text { Cohort 2: } \\
\text { 1998-2002, } \\
5.8 \text { years }\end{array}$} & \multirow{2}{*}{$\begin{array}{l}78326 \text { men } \\
\text { and women, } \\
\text { age } 40-59 \\
\text { (cohort } 1 \text { ) and } \\
40-69 \text { (cohort } \\
\text { 2), } 522 \text { cases }\end{array}$} & \multirow{2}{*}{$\begin{array}{l}\text { Validated food } \\
\text { frequency } \\
\text { questionnaire } \\
138 \text { food items, } \\
\text { AOAC method }\end{array}$} & $\begin{array}{l}\text { Dietary fibre, } \\
\text { men }\end{array}$ & $18.7 \vee 6.4 \mathrm{~g} /$ day & 0.85 (0.53 to 1.4$)$ & \multirow{2}{*}{$\begin{array}{l}\text { Age, alcohol, } \\
\text { smoking, body } \\
\text { mass index, } \\
\text { physical exercise, } \\
\text { folate, calcium, } \\
\text { vitamin } D, \text { red meat, } \\
\text { study area, energy }\end{array}$} \\
\hline & & & & & $\begin{array}{l}\text { Dietary fibre, } \\
\text { women }\end{array}$ & $20.0 v 8.3 \mathrm{~g} /$ day & $0.58(0.31$ to 1.1$)$ & \\
\hline \multirow[t]{5}{*}{$\begin{array}{l}\text { Bingham } \\
2005^{8} \\
\text { Europe }\end{array}$} & \multirow{5}{*}{$\begin{array}{l}\text { European } \\
\text { Prospective } \\
\text { Investigation } \\
\text { into Cancer } \\
\text { and Nutrition }\end{array}$} & \multirow[t]{5}{*}{$\begin{array}{l}1992-2004 \\
6.2 \text { years }\end{array}$} & \multirow{5}{*}{$\begin{array}{l}519978 \text { men } \\
\text { and women, } \\
\text { age } 25-70, \\
1721 \text { cases }\end{array}$} & \multirow{5}{*}{$\begin{array}{l}\text { Validated food } \\
\text { frequency } \\
\text { questionnaire, } \\
300-350 \text { food } \\
\text { items, diet } \\
\text { records, } \\
\text { Englyst method } \\
\text { (UK) }\end{array}$} & Dietary fibre & $\begin{array}{c}30.1 / 24.3 v 18.2 / 15.9 \\
\text { g/day, men and } \\
\text { women }\end{array}$ & 0.79 (0.63 to 0.99$)$ & \multirow{5}{*}{$\begin{array}{l}\text { Age, sex, energy } \\
\text { from non-fat } \\
\text { sources, energy } \\
\text { from fat sources, } \\
\text { height, weight, } \\
\text { folate, red and } \\
\text { processed meat, } \\
\text { physical activity, } \\
\text { alcohol, smoking } \\
\text { status, educational } \\
\text { level }\end{array}$} \\
\hline & & & & & Fruit fibre & $\begin{array}{c}5.3 / 5.4 v 2.7 / 2.8 \\
\text { g/day }\end{array}$ & 0.81 (0.68 to 0.97$)$ & \\
\hline & & & & & Cereal fibre & $\begin{array}{c}13.1 / 9.2 \vee 6.6 / 4.9 \\
\text { g/day }\end{array}$ & 0.93 (0.76 to 1.15$)$ & \\
\hline & & & & & Vegetable fibre & $\begin{array}{c}5.3 / 5.4 v 2.7 / 2.8 \\
\text { g/day }\end{array}$ & 0.94 (0.76 to 1.16$)$ & \\
\hline & & & & & Legume fibre & $1.9 / 1.0 \vee 0 \mathrm{~g} /$ day & 0.98 (0.82 to 1.17 ) & \\
\hline \multirow[t]{8}{*}{$\begin{array}{l}\text { Michels } \\
2005^{21}, \text { USA }\end{array}$} & \multirow[t]{4}{*}{$\begin{array}{l}\text { Nurses' Health } \\
\text { Study }\end{array}$} & \multirow[t]{4}{*}{$\begin{array}{l}1984-2000 \\
16 \text { years }\end{array}$} & \multirow{4}{*}{$\begin{array}{l}76947 \\
\text { women, age } \\
38-63,919 \\
\text { cases }\end{array}$} & \multirow{4}{*}{$\begin{array}{l}\text { Validated food } \\
\text { frequency } \\
\text { questionnaire, } \\
131 \text { food items, } \\
\text { AOAC method }\end{array}$} & Dietary fibre & $\begin{array}{c}>14.0 v<8.0 \mathrm{~g} / 1000 \\
\mathrm{kcal} / \mathrm{day}\end{array}$ & $0.98(0.70$ to 1.37$)$ & \multirow{8}{*}{$\begin{array}{l}\text { Age, time period, } \\
\text { family history of } \\
\text { colorectal cancer, } \\
\text { sigmoidoscopy or } \\
\text { colonoscopy, } \\
\text { height, body mass } \\
\text { index, physical } \\
\text { activity, aspirin use } \\
\text { and duration, pack } \\
\text { - years of early onse } \\
\text { smoking, } \\
\text { multivitamins, } \\
\text { energy, alcohol, } \\
\text { dietary folate, } \\
\text { calcium, red meat, } \\
\text { processed meat, } \\
\text { glycaemic load, } \\
\text { methionine, HRT } \\
\text { (women), } \\
\text { menopausal status } \\
\text { (women) }\end{array}$} \\
\hline & & & & & Cereal fibre & $\begin{array}{c}11.45 \vee 2.8 \mathrm{~g} / 1000 \\
\mathrm{kcal} / \mathrm{day}\end{array}$ & $0.79(0.60$ to 1.05$)$ & \\
\hline & & & & & Fruit fibre & $\begin{array}{c}9.3 \times 1.4 \mathrm{~g} / 1000 \\
\mathrm{kcal} / \mathrm{day}\end{array}$ & $0.92(0.68$ to 1.23$)$ & \\
\hline & & & & & Vegetable fibre & $\begin{array}{c}12.2 \text { v } 3.6 \mathrm{~g} / 1000 \\
\mathrm{kcal} / \mathrm{day}\end{array}$ & 1.09 (0.83 to 1.42$)$ & \\
\hline & \multirow{4}{*}{$\begin{array}{l}\text { Health } \\
\text { Professionals } \\
\text { Follow-up } \\
\text { Study }\end{array}$} & \multirow[t]{4}{*}{$\begin{array}{l}1986-2000 \\
14 \text { years }\end{array}$} & \multirow{4}{*}{$\begin{array}{l}47279 \text { men, } \\
\text { age } 40-75, \\
593 \text { cases }\end{array}$} & \multirow{4}{*}{$\begin{array}{l}\text { Validated food } \\
\text { frequency } \\
\text { questionnaire, } \\
131 \text { food items, } \\
\text { AOAC method }\end{array}$} & Dietary fibre & $\begin{array}{c}>14.0 v<8.0 \mathrm{~g} / 1000 \\
\mathrm{kcal} / \text { day }\end{array}$ & 0.91 (0.65 to 1.28$)$ & \\
\hline & & & & & Cereal fibre & $\begin{array}{c}8.0 v 2.3 \mathrm{~g} / 1000 \\
\mathrm{kcal} / \mathrm{day}\end{array}$ & 0.89 (0.71 to 1.12$)$ & \\
\hline & & & & & Fruit fibre & $\begin{array}{c}7.3 v 1.4 \mathrm{~g} / 1000 \\
\mathrm{kcal} / \mathrm{day}\end{array}$ & 0.88 (0.68 to 1.13$)$ & \\
\hline & & & & & Vegetable fibre & $\begin{array}{c}10.0 \text { v } 3.6 \mathrm{~g} / 1000 \\
\mathrm{kcal} / \mathrm{day}\end{array}$ & $1.20(0.94$ to 1.56$)$ & \\
\hline
\end{tabular}


Table 1 (continued)

\begin{tabular}{|c|c|c|c|c|c|c|c|c|}
\hline $\begin{array}{l}\text { Study, } \\
\text { country }\end{array}$ & Study name & $\begin{array}{l}\text { Follow-up } \\
\text { period }\end{array}$ & $\begin{array}{l}\text { Study size, } \\
\text { sex, age, No } \\
\text { of cases* }\end{array}$ & $\begin{array}{c}\text { Diet } \\
\text { assessment, } \\
\text { No of items, } \\
\text { fibre definition }\end{array}$ & Exposure & Quantity & $\begin{array}{l}\text { Relative risk (95\% } \\
\text { Cl) }\end{array}$ & $\begin{array}{l}\text { Adjustment for } \\
\text { confounders }\end{array}$ \\
\hline \multirow{5}{*}{$\begin{array}{l}\text { Lin } 2005^{22} \\
\text { USA }\end{array}$} & \multirow{5}{*}{$\begin{array}{l}\text { Women's } \\
\text { Health Study }\end{array}$} & \multirow{5}{*}{$\begin{array}{l}1993-2003 \\
10 \text { years }\end{array}$} & \multirow{5}{*}{$\begin{array}{l}39976 \\
\text { women, age } \\
\geq 45,223 \\
\text { cases }\end{array}$} & \multirow{5}{*}{$\begin{array}{l}\text { Validated food } \\
\text { frequency } \\
\text { questionnaire, } \\
131 \text { food items, } \\
\text { AOAC method }\end{array}$} & Total fibre & 26 v 12 g/day & $0.75(0.47$ to 1.18$)$ & \multirow{5}{*}{$\begin{array}{l}\text { Age, body mass } \\
\text { index, randomised } \\
\text { treatment } \\
\text { assignment, family } \\
\text { history of colorectal } \\
\text { cancer, colon } \\
\text { polyps, physical } \\
\text { activity, smoking } \\
\text { status, aspirin, red } \\
\text { meat, alcohol, } \\
\text { energy, } \\
\text { menopausal status, } \\
\text { HRT }\end{array}$} \\
\hline & & & & & Fruit fibre & 6.0 v $2.5 \mathrm{~g} / \mathrm{day}$ & 1.00 (0.67 to 1.49$)$ & \\
\hline & & & & & Vegetable fibre & $8.0 \vee 5.9 \mathrm{~g} /$ day & $1.00(0.65$ to 1.56$)$ & \\
\hline & & & & & Cereal fibre & $6.1 \vee 3.1 \mathrm{~g} /$ day & 0.97 (0.66 to 1.42$)$ & \\
\hline & & & & & Legume fibre & $1.8 \vee 0.4 \mathrm{~g} / \mathrm{day}$ & $0.60(0.40$ to 0.91$)$ & \\
\hline $\begin{array}{l}\text { Sanjoaquin } \\
2004^{20} \\
\text { England }\end{array}$ & $\begin{array}{l}\text { Oxford } \\
\text { Vegetarian } \\
\text { Study }\end{array}$ & $\begin{array}{l}\text { 1980-9, } 17 \\
\text { years }\end{array}$ & $\begin{array}{l}10998 \text { men } \\
\text { and women, } \\
\text { age 16-89: } 95 \\
\text { cases }\end{array}$ & $\begin{array}{l}\text { Validated food } \\
\text { frequency } \\
\text { questionnaire, } \\
\text { NA }\end{array}$ & $\begin{array}{l}\text { Total dietary } \\
\text { fibre }\end{array}$ & $36.7 \vee 17.0 \mathrm{~g} / \mathrm{day}$ & $0.82(0.43$ to 1.56$)$ & $\begin{array}{l}\text { Age, sex, alcohol, } \\
\text { smoking }\end{array}$ \\
\hline \multirow[t]{2}{*}{$\begin{array}{l}\text { McCullough } \\
2003^{36}, \text { USA }\end{array}$} & \multirow{2}{*}{$\begin{array}{l}\text { Cancer } \\
\text { Prevention } \\
\text { Study } 2 \\
\text { Nutrition } \\
\text { Cohort }\end{array}$} & \multirow[t]{2}{*}{$\begin{array}{l}1992-7,4.5 \\
\text { years }\end{array}$} & \multirow{2}{*}{$\begin{array}{l}62609 \text { men } \\
\text { and } 70554 \\
\text { women, age } \\
50-74,298 \\
\text { and } 210 \\
\text { cases }\end{array}$} & \multirow{2}{*}{$\begin{array}{l}\text { Validated food } \\
\text { frequency } \\
\text { questionnaire, } \\
68 \text { food items, } \\
\text { NA }\end{array}$} & $\begin{array}{l}\text { Dietary fibre, } \\
\text { men }\end{array}$ & $\geq 16.6 v<9.3 \mathrm{~g} /$ day & $1.11(0.72$ to 1.70$)$ & \multirow[b]{2}{*}{$\begin{array}{l}\text { Age, exercise } \\
\text { metabolic } \\
\text { equivalent of tasks, } \\
\text { body mass index, } \\
\text { aspirin, smoking, } \\
\text { family history of } \\
\text { colorectal cancer, } \\
\text { education, energy, } \\
\text { multivitamins, total } \\
\text { calcium, red meat } \\
\text { intake, and HRT } \\
\text { (women) }\end{array}$} \\
\hline & & & & & $\begin{array}{l}\text { Dietary fibre, } \\
\text { women }\end{array}$ & $\geq 14.4 v<8.0 \mathrm{~g} / \mathrm{day}$ & 0.86 (0.52 to 1.42$)$ & \\
\hline \multirow[t]{5}{*}{$\begin{array}{l}\text { Mai } 2003^{18} \text {, } \\
\text { USA }\end{array}$} & \multirow{5}{*}{$\begin{array}{l}\text { Breast Cancer } \\
\text { Detection } \\
\text { Demonstration } \\
\text { Project }\end{array}$} & \multirow[t]{5}{*}{$\begin{array}{l}\text { 1987-8, } 8.5 \\
\text { years }\end{array}$} & \multirow{5}{*}{$\begin{array}{l}45491 \\
\text { women, mean } \\
\text { age } 62,487 \\
\text { cases }\end{array}$} & \multirow{5}{*}{$\begin{array}{l}\text { Validated food } \\
\text { frequency } \\
\text { questionnaire, } \\
62 \text { food items, } \\
\text { NA }\end{array}$} & Total fibre & $\begin{array}{c}>12 v<6.3 \mathrm{~g} / 1000 \\
\mathrm{kcal} / \text { day }\end{array}$ & $0.94(0.70$ to 1.26$)$ & \multirow{5}{*}{$\begin{array}{l}\text { Age, non-steroidal } \\
\text { anti-inflammatory } \\
\text { drugs, smoking, } \\
\text { alcohol, calcium, } \\
\text { vitamin D, red meat, } \\
\text { height, body mass } \\
\text { index, education }\end{array}$} \\
\hline & & & & & Fruit fibre & $\begin{array}{c}>3.57 v<0.90 \mathrm{~g} / 1000 \\
\mathrm{kcal} / \mathrm{day}\end{array}$ & $1.10(0.83$ to 1.46$)$ & \\
\hline & & & & & Vegetable fibre & $\begin{array}{c}>3.48 v<1.44 \mathrm{~g} / 1000 \\
\mathrm{kcal} / \mathrm{day}\end{array}$ & $0.92(0.69$ to 1.21$)$ & \\
\hline & & & & & Bean fibre & $\begin{array}{c}>1.38 v<0.20 \mathrm{~g} / 1000 \\
\mathrm{kcal} / \mathrm{day}\end{array}$ & $0.84(0.63$ to 1.10$)$ & \\
\hline & & & & & Grain fibre & $\begin{array}{c}>4.75 \mathrm{v}<1.80 \mathrm{~g} / 1000 \\
\mathrm{kcal} / \mathrm{day}\end{array}$ & 1.02 (0.76 to 1.37$)$ & \\
\hline \multirow{4}{*}{$\begin{array}{l}\text { Terry } \\
2001^{17} \\
\text { Sweden }\end{array}$} & \multirow{4}{*}{$\begin{array}{l}\text { Swedish } \\
\text { Mammography } \\
\text { Cohort Study }\end{array}$} & \multirow{4}{*}{$\begin{array}{l}1987-98, \\
9.6 \text { years }\end{array}$} & \multirow{4}{*}{$\begin{array}{l}61463 \\
\text { women, age } \\
40-74,460 \\
\text { cases }\end{array}$} & \multirow{4}{*}{$\begin{array}{l}\text { Food frequency } \\
\text { questionnaire, } \\
67 \text { items, } \\
\text { AOAC method }\end{array}$} & Cereal fibre & $13.6 \vee 5.7 \mathrm{~g} /$ day & $0.91(0.69$ to 1.20$)$ & \multirow{4}{*}{$\begin{array}{l}\text { Age, red meat, } \\
\text { dairy products, } \\
\text { energy }\end{array}$} \\
\hline & & & & & $\begin{array}{l}\text { Total dietary } \\
\text { fibre }\end{array}$ & 21.8 v $12.3 \mathrm{~g} /$ day & $0.96(0.70$ to 1.33$)$ & \\
\hline & & & & & Fruit fibre & $5.2 \vee 0.8 \mathrm{~g} / \mathrm{day}$ & 0.97 (0.69 to 1.38$)$ & \\
\hline & & & & & Vegetable fibre & $2.5 \vee 0.6 \mathrm{~g} /$ day & $1.17(0.85$ to 1.61$)$ & \\
\hline $\begin{array}{l}\text { Pietinen } \\
1999^{16} \\
\text { Finland }\end{array}$ & $\begin{array}{l}\text { ATBC Cancer } \\
\text { Prevention } \\
\text { Study }\end{array}$ & $\begin{array}{l}\text { 1985-95, } 8 \\
\text { years }\end{array}$ & $\begin{array}{l}27111 \text { male } \\
\text { smokers, age } \\
50-69,185 \\
\text { cases }\end{array}$ & $\begin{array}{l}\text { Validated food } \\
\text { frequency } \\
\text { questionnaire, } \\
276 \text { items, } \\
\text { Englyst method }\end{array}$ & Dietary fibre & $34.1 v 16.0 \mathrm{~g} /$ day & $1.0(0.6$ to 1.5$)$ & $\begin{array}{l}\text { Age, tobacco years, } \\
\text { body mass index, } \\
\text { alcohol, education, } \\
\text { physical activity, } \\
\text { calcium, energy }\end{array}$ \\
\hline $\begin{array}{l}\text { Kato } 1997^{15} \text {, } \\
\text { USA }\end{array}$ & $\begin{array}{l}\text { New York } \\
\text { University } \\
\text { Women's Cohort } \\
\text { Study }\end{array}$ & $\begin{array}{l}1985-94 \\
\text { mean } 7.1 \\
\text { years }\end{array}$ & $\begin{array}{l}15785 \text { women, } \\
\text { age } 34-65,100 \\
\text { cases }\end{array}$ & $\begin{array}{l}\text { Food frequency } \\
\text { questionnaire, } \\
70 \text { items, NA }\end{array}$ & Dietary fibre & Fourths: $4 v 1$ & 1.51 (0.85 to 2.68$)$ & $\begin{array}{l}\text { Age, energy, place } \\
\text { at enrolment, highest } \\
\text { level of education }\end{array}$ \\
\hline \multirow{2}{*}{$\begin{array}{l}\text { Gaard } \\
1996^{14} \\
\text { Norway }\end{array}$} & \multirow{2}{*}{$\begin{array}{l}\text { Norwegian } \\
\text { National Health } \\
\text { Screening } \\
\text { Study }\end{array}$} & \multirow{2}{*}{$\begin{array}{l}1977-91 \\
11.4 \text { years }\end{array}$} & \multirow{2}{*}{$\begin{array}{l}50535 \text { men } \\
\text { and women, } \\
\text { age } 20-54, \\
143 \text { cases of } \\
\text { colon cancer }\end{array}$} & \multirow{2}{*}{$\begin{array}{l}\text { Validated food } \\
\text { frequency } \\
\text { questionnaire, } \\
80 \text { food items, } \\
\text { NA }\end{array}$} & Fibre, men & $\geq 17.9 v \leq 13.5 \mathrm{~g} /$ day & $0.82(0.46$ to 1.46$)$ & \multirow{2}{*}{$\begin{array}{l}\text { Age, body mass } \\
\text { index, height, } \\
\text { smoking status, } \\
\text { energy }\end{array}$} \\
\hline & & & & & Fibre, women & $\geq 11.3 v 8.5 \mathrm{~g} /$ day & $2.10(0.90$ to 4.87$)$ & \\
\hline
\end{tabular}


Table 1 (continued)

\begin{tabular}{|c|c|c|c|c|c|c|c|c|}
\hline $\begin{array}{l}\text { Study, } \\
\text { country }\end{array}$ & Study name & $\begin{array}{l}\text { Follow-up } \\
\text { period }\end{array}$ & $\begin{array}{l}\text { Study size, } \\
\text { sex, age, No } \\
\text { of cases* }\end{array}$ & $\begin{array}{c}\text { Diet } \\
\text { assessment, } \\
\text { No of items, } \\
\text { fibre definition }\end{array}$ & Exposure & Quantity & $\begin{array}{l}\text { Relative risk ( } 95 \% \\
\text { Cl) }\end{array}$ & $\begin{array}{l}\text { Adjustment for } \\
\text { confounders }\end{array}$ \\
\hline $\begin{array}{l}\text { Steinmetz } \\
1994^{13}, \text { USA }\end{array}$ & $\begin{array}{l}\text { lowa Women's } \\
\text { Health Study }\end{array}$ & $\begin{array}{l}1986-91,5 \\
\text { years }\end{array}$ & $\begin{array}{l}41837 \text { women, } \\
\text { age } 55-69,212 \\
\text { cases of colon } \\
\text { cancer }\end{array}$ & $\begin{array}{l}\text { Validated food } \\
\text { frequency } \\
\text { questionnaire, } \\
127 \text { food items, } \\
\text { NA }\end{array}$ & Dietary fibre & $>24.7 v<14.5 \mathrm{~g} /$ day & $0.80(0.49$ to 1.31$)$ & Age, energy \\
\hline \multirow[t]{2}{*}{$\begin{array}{l}\text { Heilbrun } \\
1989^{12}, \text { USA }\end{array}$} & \multirow[t]{2}{*}{$\begin{array}{l}\text { Honolulu Heart } \\
\text { Program }\end{array}$} & \multirow[t]{2}{*}{$\begin{array}{l}1965-85 \\
16 \text { years }\end{array}$} & \multirow{2}{*}{$\begin{array}{l}8006 \\
\text { American } \\
\text { Japanese } \\
\text { men: } 102 \\
\text { cases of } \\
\text { colon cancer, } \\
60 \text { cases of } \\
\text { rectal cancer, } \\
361 \text { controls }\end{array}$} & \multirow{2}{*}{$\begin{array}{l}\text { Dietary recall, } \\
24 \text { hour, } 54 \\
\text { food items, NA }\end{array}$} & $\begin{array}{l}\text { Dietary fibre, } \\
\text { colon cancer }\end{array}$ & $\geq 14.80 v<7.50 \mathrm{~g} /$ day & 0.71 (0.38 to 1.32$)$ & \multirow[t]{2}{*}{ Age, alcohol intake } \\
\hline & & & & & $\begin{array}{l}\text { Dietary fibre, } \\
\text { rectal cancer }\end{array}$ & $\geq 14.80 v<7.50 \mathrm{~g} / \mathrm{day}$ & $1.20(0.51$ to 2.83$)$ & \\
\hline \multirow[t]{2}{*}{$\begin{array}{l}\text { Wu } 1987^{11} \\
\text { USA }\end{array}$} & \multirow[t]{2}{*}{$\begin{array}{l}\text { Leisure World } \\
\text { Cohort Study }\end{array}$} & \multirow[t]{2}{*}{$\begin{array}{l}1981-5,3.5 \\
\text { years }\end{array}$} & \multirow{2}{*}{$\begin{array}{l}11564 \text { men } \\
\text { and women, } \\
\text { age } \leq 64 \text { to } \\
\geq 85,58 \text { and } \\
68 \text { cases }\end{array}$} & \multirow{2}{*}{$\begin{array}{l}\text { Validated food } \\
\text { frequency } \\
\text { questionnaire, } \\
56 \text { food items, } \\
\text { NA }\end{array}$} & $\begin{array}{l}\text { Dietary fibre, } \\
\text { men }\end{array}$ & Thirds: $3 v 1$ & $1.13(0.60$ to 2.10$)$ & \multirow[t]{2}{*}{ Age } \\
\hline & & & & & $\begin{array}{l}\text { Dietary fibre, } \\
\text { women }\end{array}$ & Thirds: $3 v 1$ & $0.64(0.40$ to 1.20$)$ & \\
\hline
\end{tabular}

$\mathrm{NA}=$ not available; $\mathrm{HRT}=$ hormone replacement therapy; $\mathrm{AOAC}=$ Association of Official Analytical Chemists. ${ }^{*}$ Cases refer to colorectal cancer unless specified otherwise. 


\section{Table 2| Prospective studies of whole grain intake and incidence of colorectal cancer}

\begin{tabular}{|c|c|c|c|c|c|c|c|c|}
\hline $\begin{array}{l}\text { Study, } \\
\text { country }\end{array}$ & Study name & $\begin{array}{l}\text { Follow-up } \\
\text { period }\end{array}$ & $\begin{array}{l}\text { Study size, sex, } \\
\text { age, No of cases }{ }^{*}\end{array}$ & $\begin{array}{l}\text { Diet assessment, } \\
\text { No of items }\end{array}$ & Exposure & Quantity & $\begin{array}{c}\text { Relative risk } \\
(95 \% \mathrm{Cl})\end{array}$ & $\begin{array}{l}\text { Adjustment for } \\
\text { confounders }\end{array}$ \\
\hline $\begin{array}{l}\text { Fung } 2010^{39} \text {, } \\
\text { USA }\end{array}$ & $\begin{array}{l}\text { Nurses' Health } \\
\text { Study }\end{array}$ & $\begin{array}{l}1980-2006, \\
26 \text { years }\end{array}$ & $\begin{array}{l}87256 \text { women, } \\
\text { age } 34-59,1432 \\
\text { cases }\end{array}$ & $\begin{array}{l}\text { Validated food } \\
\text { frequency } \\
\text { questionnaire, } \\
61-116 \text { food items }\end{array}$ & Whole grains & $\begin{array}{l}\text { Per } \\
\text { serving/day }\end{array}$ & $\begin{array}{l}0.95 \text { ( } 0.89 \text { to } \\
1.02)\end{array}$ & $\begin{array}{l}\text { Age, body mass index, } \\
\text { alcohol, family history of } \\
\text { colorectal cancer, physical } \\
\text { activity, aspirin, } \\
\text { colonoscopy, history of } \\
\text { polyps, pack years of } \\
\text { smoking, energy, } \\
\text { multivitamins }\end{array}$ \\
\hline
\end{tabular}

\begin{tabular}{|c|c|c|c|c|c|c|c|c|}
\hline $\begin{array}{l}\text { Fung } 2010^{39} \text {, } \\
\text { USA }\end{array}$ & $\begin{array}{l}\text { Health } \\
\text { Professionals } \\
\text { Follow-Up } \\
\text { Study }\end{array}$ & $\begin{array}{l}1986-2006, \\
20 \text { years }\end{array}$ & $\begin{array}{l}45490 \text { men, age } \\
40-75,1032 \text { cases }\end{array}$ & $\begin{array}{l}\text { Validated food } \\
\text { frequency } \\
\text { questionnaire, } \\
\text { about } 140 \text { food } \\
\text { items }\end{array}$ & Whole grains & $\begin{array}{l}\text { Per } \\
\text { serving/day }\end{array}$ & $\begin{array}{l}0.94 \text { (0.88 to } \\
0.99)\end{array}$ & $\begin{array}{l}\text { Age, body mass index, } \\
\text { alcohol, family history of } \\
\text { colorectal cancer, physical } \\
\text { activity, aspirin, } \\
\text { colonoscopy, history of } \\
\text { polyps, pack years of } \\
\text { smoking, energy, } \\
\text { multivitamins }\end{array}$ \\
\hline \multirow[t]{4}{*}{$\begin{array}{l}\text { Egeberg } \\
2010^{38} \\
\text { Denmark }\end{array}$} & \multirow{4}{*}{$\begin{array}{l}\text { The Diet } \\
\text { Cancer and } \\
\text { Health Cohort } \\
\text { Study }\end{array}$} & \multirow[t]{4}{*}{$\begin{array}{l}1993-2006, \\
10.2 \text { years }\end{array}$} & \multirow{4}{*}{$\begin{array}{l}26630 \text { men and } \\
29189 \text { women, } \\
\text { age } 50-64,461 \\
\text { cases of colon } \\
\text { cancer and } 283 \\
\text { cases of rectal } \\
\text { cancer }\end{array}$} & \multirow{4}{*}{$\begin{array}{l}\text { Validated food } \\
\text { frequency } \\
\text { questionnaire, } 192 \\
\text { food items }\end{array}$} & $\begin{array}{l}\text { Whole grains, } \\
\text { colon cancer, } \\
\text { men }\end{array}$ & $\begin{array}{l}>160 v \leq 75 \\
\text { g/day }\end{array}$ & $\begin{array}{l}0.61(0.43 \text { to } \\
0.86)\end{array}$ & \multirow{4}{*}{$\begin{array}{l}\text { Age, body mass index, } \\
\text { alcohol intake, school } \\
\text { education, red and } \\
\text { processed meat, HRT } \\
\text { (women), leisure time } \\
\text { physical activity }\end{array}$} \\
\hline & & & & & $\begin{array}{l}\text { Whole grains, } \\
\text { rectal cancer, } \\
\text { men }\end{array}$ & $\begin{array}{l}>160 v \leq 75 \\
\text { g/day }\end{array}$ & $\begin{array}{l}0.88(0.57 \text { to } \\
1.36)\end{array}$ & \\
\hline & & & & & $\begin{array}{l}\text { Whole grains, } \\
\text { colon cancer, } \\
\text { women }\end{array}$ & $\begin{array}{l}>160 v \leq 75 \\
\text { g/day }\end{array}$ & $\begin{array}{l}0.92(0.63 \text { to } \\
1.35)\end{array}$ & \\
\hline & & & & & $\begin{array}{l}\text { Whole grains, } \\
\text { rectal cancer, } \\
\text { women }\end{array}$ & $\begin{array}{l}>160 v \leq 75 \\
\text { g/day }\end{array}$ & $\begin{array}{l}0.81(0.50 \text { to } \\
1.30)\end{array}$ & \\
\hline $\begin{array}{l}\text { Schatzkin } \\
2007^{27}, \text { USA }\end{array}$ & $\begin{array}{l}\text { NIH-AARP Diet } \\
\text { and Health } \\
\text { Study }\end{array}$ & $\begin{array}{l}1995-2000, \\
5 \text { years }\end{array}$ & $\begin{array}{l}291988 \text { men and } \\
197623 \text { women, } \\
\text { age } 50-71,2974 \\
\text { cases }\end{array}$ & $\begin{array}{l}\text { Validated food } \\
\text { frequency } \\
\text { questionnaire, } 124 \\
\text { food items }\end{array}$ & Whole grains & $\begin{array}{l}1.3 \vee 0.2 \\
\text { serv/1000 } \\
\mathrm{kcal} / \text { day }\end{array}$ & $\begin{array}{l}0.79(0.70 \text { to } \\
0.89)\end{array}$ & $\begin{array}{l}\text { Age, sex, physical activity, } \\
\text { smoking, HRT (women), red } \\
\text { meat, dietary calcium, } \\
\text { dietary folate, energy }\end{array}$ \\
\hline $\begin{array}{l}\text { McCarl } \\
2006^{25}, \text { USA }\end{array}$ & $\begin{array}{l}\text { lowa Women's } \\
\text { Health Study }\end{array}$ & $\begin{array}{l}1986-2000 \\
14 \text { years }\end{array}$ & $\begin{array}{l}35197 \text { women, } \\
\text { age } 55-69,954 \\
\text { cases }\end{array}$ & $\begin{array}{l}\text { Validated food } \\
\text { frequency } \\
\text { questionnaire, } 127 \\
\text { food items }\end{array}$ & Whole grains & $\begin{array}{l}\geq 19 v \leq 3.5 \\
\text { servings/week }\end{array}$ & $\begin{array}{l}0.81(0.66 \text { to } \\
0.99)\end{array}$ & Age \\
\hline $\begin{array}{l}\text { Larsson } \\
2005^{35} \\
\text { Sweden }\end{array}$ & $\begin{array}{l}\text { Swedish } \\
\text { Mammography } \\
\text { Cohort Study }\end{array}$ & $\begin{array}{l}1987-2004 \\
14.8 \text { years }\end{array}$ & $\begin{array}{l}61433 \text { women, } \\
\text { age } 40-76,805 \\
\text { cases }\end{array}$ & $\begin{array}{l}\text { Validated food } \\
\text { frequency } \\
\text { questionnaire, } 67 \\
\text { food items }\end{array}$ & Whole grain & $\begin{array}{l}\geq 4.5 v<1.5 \\
\text { servings/day }\end{array}$ & $\begin{array}{l}0.80(0.60 \text { to } \\
1.06)\end{array}$ & $\begin{array}{l}\text { Age, body mass index, } \\
\text { education, energy, saturated } \\
\text { fat, calcium, red meat, fruits } \\
\text { and vegetables }\end{array}$ \\
\hline $\begin{array}{l}\text { Wu } 2004^{37}, \\
\text { USA }\end{array}$ & $\begin{array}{l}\text { Health } \\
\text { Professional's } \\
\text { Follow-up } \\
\text { Study }\end{array}$ & $\begin{array}{l}1986-2000 \\
14 \text { years }\end{array}$ & $\begin{array}{l}47311 \text { men, age } \\
45-75,561 \text { cases } \\
\text { of colon cancer }\end{array}$ & $\begin{array}{l}\text { Validated food } \\
\text { frequency } \\
\text { questionnaire, } 131 \\
\text { food items }\end{array}$ & Whole grain & Fifths: $5 v 1$ & $\begin{array}{l}0.75(0.57 \text { to } \\
1.00)\end{array}$ & $\begin{array}{l}\text { Age, family history of } \\
\text { colorectal cancer in first } \\
\text { degree relative, history of } \\
\text { endoscopy, physical activity, } \\
\text { pack years of smoking } \\
\text { before age } 30 \text {, race, aspirin } \\
\text { use, energy }\end{array}$ \\
\hline \multirow[t]{2}{*}{$\begin{array}{l}\text { McCullough } \\
2003^{36}, \text { USA }\end{array}$} & \multirow{2}{*}{$\begin{array}{l}\text { Cancer } \\
\text { Prevention } \\
\text { Study } 2\end{array}$} & \multirow[t]{2}{*}{$\begin{array}{l}1992-7,4.5 \\
\text { years }\end{array}$} & \multirow{2}{*}{$\begin{array}{l}62609 \text { men and } \\
70554 \text { women, } \\
\text { age } 50-74, \\
298 / 210 \text { cases of } \\
\text { colon cancer }\end{array}$} & \multirow{2}{*}{$\begin{array}{l}\text { Validated food } \\
\text { frequency } \\
\text { questionnaire, } 68 \\
\text { items }\end{array}$} & $\begin{array}{l}\text { Whole grains, } \\
\text { men }\end{array}$ & $\begin{array}{l}\geq 11.0 \mathrm{v} .<2.0 \\
\text { servings/week }\end{array}$ & $\begin{array}{l}0.95(0.64 \text { to } \\
1.42)\end{array}$ & \multirow{2}{*}{$\begin{array}{l}\text { Age, exercise metabolic } \\
\text { equivalent of tasks, aspirin, } \\
\text { smoking, family history of } \\
\text { colorectal cancer, body } \\
\text { mass index, education, } \\
\text { energy, multivitamin use, } \\
\text { total calcium, red meat } \\
\text { intake, and HRT (women) }\end{array}$} \\
\hline & & & & & $\begin{array}{l}\text { Whole grains, } \\
\text { women }\end{array}$ & $\begin{array}{l}\geq 11.2 v<2.5 \\
\text { servings/week }\end{array}$ & $\begin{array}{l}1.17(0.73 \text { to } \\
1.87)\end{array}$ & \\
\hline
\end{tabular}

\begin{tabular}{|c|c|c|c|c|c|c|c|c|}
\hline $\begin{array}{l}\text { Fung } 2010^{39} \text {, } \\
\text { USA }\end{array}$ & $\begin{array}{l}\text { Health } \\
\text { Professionals } \\
\text { Follow-Up } \\
\text { Study }\end{array}$ & $\begin{array}{l}1986-2006, \\
20 \text { years }\end{array}$ & $\begin{array}{l}45490 \text { men, age } \\
40-75,1032 \text { cases }\end{array}$ & $\begin{array}{l}\text { Validated food } \\
\text { frequency } \\
\text { questionnaire, } \\
\text { about } 140 \text { food } \\
\text { items }\end{array}$ & Whole grains & $\begin{array}{l}\text { Per } \\
\text { serving/day }\end{array}$ & $\begin{array}{l}0.94 \text { (0.88 to } \\
0.99)\end{array}$ & $\begin{array}{l}\text { Age, body mass index, } \\
\text { alcohol, family history of } \\
\text { colorectal cancer, physical } \\
\text { activity, aspirin, } \\
\text { colonoscopy, history of } \\
\text { polyps, pack years of } \\
\text { smoking, energy, } \\
\text { multivitamins }\end{array}$ \\
\hline \multirow[t]{4}{*}{$\begin{array}{l}\text { Egeberg } \\
2010^{38} \\
\text { Denmark }\end{array}$} & \multirow{4}{*}{$\begin{array}{l}\text { The Diet } \\
\text { Cancer and } \\
\text { Health Cohort } \\
\text { Study }\end{array}$} & \multirow{4}{*}{$\begin{array}{l}1993-2006 \\
10.2 \text { years }\end{array}$} & \multirow{4}{*}{$\begin{array}{l}26630 \text { men and } \\
29189 \text { women, } \\
\text { age } 50-64,461 \\
\text { cases of colon } \\
\text { cancer and } 283 \\
\text { cases of rectal } \\
\text { cancer }\end{array}$} & \multirow{4}{*}{$\begin{array}{l}\text { Validated food } \\
\text { frequency } \\
\text { questionnaire, } 192 \\
\text { food items }\end{array}$} & $\begin{array}{l}\text { Whole grains, } \\
\text { colon cancer, } \\
\text { men }\end{array}$ & $\begin{array}{l}>160 v \leq 75 \\
\text { g/day }\end{array}$ & $\begin{array}{l}0.61(0.43 \text { to } \\
0.86)\end{array}$ & \multirow{4}{*}{$\begin{array}{l}\text { Age, body mass index, } \\
\text { alcohol intake, school } \\
\text { education, red and } \\
\text { processed meat, HRT } \\
\text { (women), leisure time } \\
\text { physical activity }\end{array}$} \\
\hline & & & & & $\begin{array}{l}\text { Whole grains, } \\
\text { rectal cancer, } \\
\text { men }\end{array}$ & $\begin{array}{l}>160 v \leq 75 \\
\text { g/day }\end{array}$ & $\begin{array}{l}0.88(0.57 \text { to } \\
1.36)\end{array}$ & \\
\hline & & & & & $\begin{array}{l}\text { Whole grains, } \\
\text { colon cancer, } \\
\text { women }\end{array}$ & $\begin{array}{l}>160 v \leq 75 \\
\text { g/day }\end{array}$ & $\begin{array}{l}0.92(0.63 \text { to } \\
1.35)\end{array}$ & \\
\hline & & & & & $\begin{array}{l}\text { Whole grains, } \\
\text { rectal cancer, } \\
\text { women }\end{array}$ & $\begin{array}{l}>160 v \leq 75 \\
\text { g/day }\end{array}$ & $\begin{array}{l}0.81(0.50 \text { to } \\
1.30)\end{array}$ & \\
\hline $\begin{array}{l}\text { Schatzkin } \\
2007^{27}, \text { USA }\end{array}$ & $\begin{array}{l}\text { NIH-AARP Diet } \\
\text { and Health } \\
\text { Study }\end{array}$ & $\begin{array}{l}1995-2000, \\
5 \text { years }\end{array}$ & $\begin{array}{l}291988 \text { men and } \\
197623 \text { women, } \\
\text { age } 50-71,2974 \\
\text { cases }\end{array}$ & $\begin{array}{l}\text { Validated food } \\
\text { frequency } \\
\text { questionnaire, } 124 \\
\text { food items }\end{array}$ & Whole grains & $\begin{array}{l}1.3 \vee 0.2 \\
\text { serv } / 1000 \\
\mathrm{kcal} / \text { day }\end{array}$ & $\begin{array}{l}0.79(0.70 \text { to } \\
0.89)\end{array}$ & $\begin{array}{l}\text { Age, sex, physical activity, } \\
\text { smoking, HRT (women), red } \\
\text { meat, dietary calcium, } \\
\text { dietary folate, energy }\end{array}$ \\
\hline $\begin{array}{l}\text { McCarl } \\
2006^{25}, \text { USA }\end{array}$ & $\begin{array}{l}\text { lowa Women's } \\
\text { Health Study }\end{array}$ & $\begin{array}{l}1986-2000, \\
14 \text { years }\end{array}$ & $\begin{array}{l}35197 \text { women, } \\
\text { age } 55-69,954 \\
\text { cases }\end{array}$ & $\begin{array}{l}\text { Validated food } \\
\text { frequency } \\
\text { questionnaire, } 127 \\
\text { food items }\end{array}$ & Whole grains & $\begin{array}{l}\geq 19 v \leq 3.5 \\
\text { servings/week }\end{array}$ & $\begin{array}{l}0.81 \text { ( } 0.66 \text { to } \\
0.99)\end{array}$ & Age \\
\hline $\begin{array}{l}\text { Larsson } \\
2005^{35} \\
\text { Sweden }\end{array}$ & $\begin{array}{l}\text { Swedish } \\
\text { Mammography } \\
\text { Cohort Study }\end{array}$ & $\begin{array}{l}1987-2004, \\
14.8 \text { years }\end{array}$ & $\begin{array}{l}61433 \text { women, } \\
\text { age } 40-76,805 \\
\text { cases }\end{array}$ & $\begin{array}{l}\text { Validated food } \\
\text { frequency } \\
\text { questionnaire, } 67 \\
\text { food items }\end{array}$ & Whole grain & $\begin{array}{l}\geq 4.5 v<1.5 \\
\text { servings/day }\end{array}$ & $\begin{array}{l}0.80(0.60 \text { to } \\
1.06)\end{array}$ & $\begin{array}{l}\text { Age, body mass index, } \\
\text { education, energy, saturated } \\
\text { fat, calcium, red meat, fruits } \\
\text { and vegetables }\end{array}$ \\
\hline $\begin{array}{l}\text { Wu } 2004^{37} \\
\text { USA }\end{array}$ & $\begin{array}{l}\text { Health } \\
\text { Professional's } \\
\text { Follow-up } \\
\text { Study }\end{array}$ & $\begin{array}{l}1986-2000 \\
14 \text { years }\end{array}$ & $\begin{array}{l}47311 \text { men, age } \\
45-75,561 \text { cases } \\
\text { of colon cancer }\end{array}$ & $\begin{array}{l}\text { Validated food } \\
\text { frequency } \\
\text { questionnaire, } 131 \\
\text { food items }\end{array}$ & Whole grain & Fifths: $5 v 1$ & $\begin{array}{l}0.75(0.57 \text { to } \\
1.00)\end{array}$ & $\begin{array}{l}\text { Age, family history of } \\
\text { colorectal cancer in first } \\
\text { degree relative, history of } \\
\text { endoscopy, physical activity, } \\
\text { pack years of smoking } \\
\text { before age } 30 \text {, race, aspirin } \\
\text { use, energy }\end{array}$ \\
\hline \multirow[t]{2}{*}{$\begin{array}{l}\text { McCullough } \\
2003^{36}, \text { USA }\end{array}$} & \multirow{2}{*}{$\begin{array}{l}\text { Cancer } \\
\text { Prevention } \\
\text { Study } 2\end{array}$} & \multirow[t]{2}{*}{$\begin{array}{l}1992-7,4.5 \\
\text { years }\end{array}$} & \multirow{2}{*}{$\begin{array}{l}62609 \text { men and } \\
70554 \text { women, } \\
\text { age } 50-74, \\
298 / 210 \text { cases of } \\
\text { colon cancer }\end{array}$} & \multirow{2}{*}{$\begin{array}{l}\text { Validated food } \\
\text { frequency } \\
\text { questionnaire, } 68 \\
\text { items }\end{array}$} & $\begin{array}{l}\text { Whole grains, } \\
\text { men }\end{array}$ & $\begin{array}{l}\geq 11.0 \mathrm{v} .<2.0 \\
\text { servings/week }\end{array}$ & $\begin{array}{l}0.95(0.64 \text { to } \\
1.42)\end{array}$ & \multirow{2}{*}{$\begin{array}{l}\text { Age, exercise metabolic } \\
\text { equivalent of tasks, aspirin, } \\
\text { smoking, family history of } \\
\text { colorectal cancer, body } \\
\text { mass index, education, } \\
\text { energy, multivitamin use, } \\
\text { total calcium, red meat } \\
\text { intake, and HRT (women) }\end{array}$} \\
\hline & & & & & $\begin{array}{l}\text { Whole grains, } \\
\text { women }\end{array}$ & $\begin{array}{l}\geq 11.2 v<2.5 \\
\text { servings/week }\end{array}$ & $\begin{array}{l}1.17(0.73 \text { to } \\
1.87)\end{array}$ & \\
\hline
\end{tabular}




\begin{tabular}{|c|c|c|c|c|c|c|c|c|c|c|c|c|c|c|c|}
\hline \multirow[b]{3}{*}{ Subgroups } & \multicolumn{5}{|c|}{ Total dietary fibre } & \multicolumn{5}{|c|}{ Fruit fibre } & \multicolumn{5}{|c|}{ Vegetable fibre } \\
\hline & \multirow{2}{*}{$\begin{array}{l}\text { No of } \\
\text { studies }\end{array}$} & \multirow{2}{*}{$\begin{array}{c}\text { Relative } \\
\text { risk (95\% } \\
\text { Cl) }\end{array}$} & \multirow{2}{*}{$\begin{array}{l}I^{2} \\
(\%)\end{array}$} & \multicolumn{2}{|c|}{$\begin{array}{c}\mathrm{P} \text { for } \\
\text { heterogeneity }\end{array}$} & \multirow{2}{*}{$\begin{array}{l}\text { No of } \\
\text { studies }\end{array}$} & \multirow{2}{*}{$\begin{array}{c}\text { Relative } \\
\text { risk (95\% } \\
\text { Cl) }\end{array}$} & \multirow{2}{*}{$\begin{array}{l}1^{2} \\
(\%)\end{array}$} & \multicolumn{2}{|c|}{$\begin{array}{c}\mathbf{P} \text { for } \\
\text { heterogeneity } \\
\end{array}$} & \multirow{2}{*}{$\begin{array}{l}\text { No of } \\
\text { studies }\end{array}$} & \multirow{2}{*}{$\begin{array}{l}\text { Relative } \\
\text { risk (95\% } \\
\text { Cl) }\end{array}$} & \multirow{2}{*}{$\begin{array}{l}1^{2} \\
(\%)\end{array}$} & \multicolumn{2}{|c|}{$\begin{array}{c}\mathrm{P} \text { for } \\
\text { heterogeneity }\end{array}$} \\
\hline & & & & * & $t$ & & & & * & $\dagger$ & & & & * & $t$ \\
\hline All studies & 16 & $\begin{array}{c}0.90 \text { (0.86 to } \\
0.94)\end{array}$ & 0 & 0.48 & - & 9 & $\begin{array}{c}0.93(0.82 \text { to } \\
1.05)\end{array}$ & 23 & 0.24 & - & 9 & $\begin{array}{c}0.98(0.91 \text { to } \\
1.06)\end{array}$ & 0 & 0.60 & - \\
\hline \multicolumn{16}{|l|}{$\begin{array}{l}\text { Duration of } \\
\text { follow-up: }\end{array}$} \\
\hline$<10$ years & 10 & $\begin{array}{c}0.91 \text { ( } 0.84 \text { to } \\
0.97)\end{array}$ & 33.2 & 0.14 & 0.77 & 6 & $\begin{array}{c}0.97(0.82 \text { to } 3 \\
1.14)\end{array}$ & 37.6 & 0.16 & 0.26 & 6 & $\begin{array}{c}0.96 \text { (0.88 to } \\
1.04)\end{array}$ & 0 & 0.51 & 0.27 \\
\hline$\geq 10$ years & 6 & $\begin{array}{c}0.91 \text { ( } 0.85 \text { to } \\
0.98)\end{array}$ & 0 & 0.97 & & 3 & $\begin{array}{c}0.80 \text { (0.64 to } \\
1.00)\end{array}$ & 0 & 0.91 & & 3 & $\begin{array}{c}1.10(0.90 \text { to } \\
1.35)\end{array}$ & 0 & 0.74 & \\
\hline \multicolumn{16}{|l|}{ Sex: } \\
\hline Men & 7 & $\begin{array}{c}0.92 \text { (0.82 to } \\
1.03)\end{array}$ & 54.4 & 0.04 & 0.72 & 2 & $\begin{array}{c}0.83(0.72 \text { to } \\
0.97)\end{array}$ & 0 & 0.80 & 0.45 & 2 & $\begin{array}{c}0.94 \text { (0.78 to } \\
1.14)\end{array}$ & 44.3 & 0.18 & 0.34 \\
\hline Women & 11 & $\begin{array}{l}0.94 \text { (0.89 to } \\
0.99)\end{array}$ & 0 & 0.74 & & 5 & $\begin{array}{c}0.91 \text { (0.78 to } \\
1.06)\end{array}$ & 0 & 0.80 & & 5 & $\begin{array}{c}1.02 \text { (0.89 to } \\
1.17)\end{array}$ & 0 & 0.54 & \\
\hline \multicolumn{16}{|l|}{ Subsite: } \\
\hline Colon & 13 & $\begin{array}{c}0.90 \text { (0.83 to } \\
0.98)\end{array}$ & 33.9 & 0.11 & 0.86 & 3 & $\begin{array}{l}0.90 \text { (0.34 to } 5 \\
2.38)\end{array}$ & 59.2 & 0.42 & 0.85 & 3 & $\begin{array}{c}0.89 \text { (0.57 to } \\
1.40)\end{array}$ & 30.9 & 0.24 & 0.24 \\
\hline Rectum & 10 & $\begin{array}{c}0.91 \text { ( } 0.83 \text { to } \\
1.03)\end{array}$ & 14.7 & 0.31 & & 1 & $\begin{array}{c}1.26 \text { (0.09 to } \\
18.24)\end{array}$ & - & - & & 1 & $\begin{array}{c}6.40 \text { (0.97 to } \\
42.34)\end{array}$ & - & - & \\
\hline \multicolumn{16}{|l|}{$\begin{array}{l}\text { Geographical } \\
\text { location: }\end{array}$} \\
\hline Europe & 4 & $\begin{array}{c}0.87 \text { (0.78 to } \\
0.96)\end{array}$ & 9.2 & 0.35 & 0.74 & 2 & $\begin{array}{c}0.75 \text { (0.46 to } \\
1.23)\end{array}$ & 0 & 0.39 & 0.34 & 2 & $\begin{array}{c}1.30(0.35 \text { to } \\
4.84)\end{array}$ & 58.2 & 0.12 & 0.70 \\
\hline USA & 9 & $\begin{array}{c}0.92 \text { (0.88 to } \\
0.96)\end{array}$ & 0 & 0.69 & & 6 & $\begin{array}{c}0.93(0.81 \text { to } 3 \\
1.07)\end{array}$ & 38.0 & 0.15 & & 6 & $\begin{array}{c}0.98 \text { (0.91 to } \\
1.06)\end{array}$ & 0 & 0.61 & \\
\hline Asia & 3 & $\begin{array}{c}0.78 \text { (0.60 to } \\
1.03)\end{array}$ & 24.7 & 0.29 & & 1 & $\begin{array}{c}1.90 \text { (0.40 to } \\
9.04)\end{array}$ & - & - & & 1 & $\begin{array}{c}0.71 \text { (0.26 to } \\
1.91)\end{array}$ & - & - & \\
\hline \multicolumn{16}{|l|}{ No of cases: } \\
\hline$<500$ & 8 & $\begin{array}{c}0.92 \text { (0.82 to } \\
1.03)\end{array}$ & 0 & 0.64 & 0.35 & 4 & $\begin{array}{c}1.08(0.73 \text { to } \\
1.60)\end{array}$ & 0 & 0.87 & 0.98 & 4 & $\begin{array}{c}1.05 \text { (0.61 to } \\
1.79)\end{array}$ & 8.0 & 0.35 & 0.37 \\
\hline $500-1499$ & 5 & $\begin{array}{c}0.92 \text { (0.87 to } \\
0.99)\end{array}$ & 0 & 0.68 & & 2 & $\begin{array}{c}0.80(0.64 \text { to } \\
1.00)\end{array}$ & 0 & 0.70 & & 2 & $\begin{array}{c}1.09 \text { (0.89 to } \\
1.34)\end{array}$ & 0 & 0.93 & \\
\hline$\geq 1500$ & 3 & $\begin{array}{c}0.88 \text { (0.80 to } \\
0.97)\end{array}$ & 64.0 & 0.06 & & 3 & $\begin{array}{c}0.94 \text { (0.75 to } \\
1.17)\end{array}$ & 71.4 & 0.03 & & 3 & $\begin{array}{c}0.96 \text { (0.88 to } \\
1.04)\end{array}$ & 0 & 0.41 & \\
\hline \multicolumn{16}{|l|}{$\begin{array}{l}\text { Range of } \\
\text { intake: }\end{array}$} \\
\hline $\begin{array}{l}<15 \text { to }<10 \\
\text { g/day } \neq\end{array}$ & 11 & $\begin{array}{c}0.90 \text { (0.84 to } \\
0.96)\end{array}$ & 11.9 & 0.33 & 0.80 & 6 & $\begin{array}{c}1.07 \text { (0.94 to } \\
1.23)\end{array}$ & 0 & 0.61 & 0.04 & 6 & $\begin{array}{c}1.03 \text { (0.89 to } \\
1.18)\end{array}$ & 0 & 0.58 & 0.54 \\
\hline $\begin{array}{l}\geq 15 \text { to } \geq 10 \\
\text { g/day } \neq\end{array}$ & 5 & $\begin{array}{c}0.90 \text { (0.85 to } \\
0.95)\end{array}$ & 0 & 0.51 & & 3 & $\begin{array}{c}0.86 \text { (0.77 to } \\
0.96)\end{array}$ & 0 & 0.71 & & 3 & $\begin{array}{c}0.96 \text { (0.88 to } \\
1.05)\end{array}$ & 0 & 0.38 & \\
\hline \multicolumn{16}{|c|}{ Adjustment for confounders } \\
\hline \multicolumn{16}{|l|}{ Alcohol: } \\
\hline Yes & 12 & $\begin{array}{c}0.87 \text { ( } 0.83 \text { to } \\
0.92)\end{array}$ & 0 & 0.63 & 0.08 & 7 & $\begin{array}{c}0.86 \text { ( } 0.78 \text { to } \\
0.96)\end{array}$ & 0 & 0.75 & 0.04 & 7 & $\begin{array}{c}0.95 \text { (0.87 to } \\
1.04)\end{array}$ & 0 & 0.75 & 0.32 \\
\hline No & 4 & $\begin{array}{c}0.95 \text { (0.88 to } \\
1.01)\end{array}$ & 0 & 0.51 & & 2 & $\begin{array}{c}1.10(0.95 \text { to } \\
1.28)\end{array}$ & 0 & 0.75 & & 2 & $\begin{array}{c}1.34 \text { (0.54 to } \\
3.34)\end{array}$ & 45.0 & 0.18 & \\
\hline \multicolumn{16}{|l|}{ Smoking: } \\
\hline Yes & 13 & $\begin{array}{c}0.90 \text { (0.85 to } \\
0.95)\end{array}$ & 15.7 & 0.29 & 0.84 & 8 & $\begin{array}{c}0.92(0.81 \text { to } \\
1.05)\end{array}$ & 32.5 & 0.17 & 0.89 & 8 & $\begin{array}{c}0.98 \text { (0.90 to } \\
1.05)\end{array}$ & 0 & 0.74 & 0.20 \\
\hline No & 3 & $\begin{array}{c}0.95 \text { (0.88 to } \\
1.01)\end{array}$ & 0 & 0.51 & & 1 & $\begin{array}{c}0.97 \text { ( } 0.45 \text { to } \\
2.09)\end{array}$ & - & - & & 1 & $\begin{array}{c}3.15 \text { (0.63 to } \\
15.64)\end{array}$ & - & - & \\
\hline
\end{tabular}


Table 3 (continued)

\begin{tabular}{|c|c|c|c|c|c|c|c|c|c|c|c|c|c|c|c|}
\hline \multirow[b]{3}{*}{ Subgroups } & \multicolumn{5}{|c|}{ Total dietary fibre } & \multicolumn{5}{|c|}{ Fruit fibre } & \multicolumn{5}{|c|}{ Vegetable fibre } \\
\hline & \multirow{2}{*}{$\begin{array}{c}\text { No of } \\
\text { studies }\end{array}$} & \multirow{2}{*}{$\begin{array}{l}\text { Relative } \\
\text { risk (95\% } \\
\text { Cl) }\end{array}$} & \multirow{2}{*}{$\begin{array}{c}I^{2} \\
(\%)\end{array}$} & \multicolumn{2}{|c|}{$\begin{array}{c}\mathrm{P} \text { for } \\
\text { heterogeneity }\end{array}$} & \multirow{2}{*}{$\begin{array}{c}\text { No of } \\
\text { studies }\end{array}$} & \multirow{2}{*}{$\begin{array}{l}\text { Relative } \\
\text { risk }(95 \% \\
\text { Cl) }\end{array}$} & \multirow{2}{*}{$\begin{array}{l}1^{2} \\
(\%)\end{array}$} & \multicolumn{2}{|c|}{$\begin{array}{c}\mathbf{P} \text { for } \\
\text { heterogeneity }\end{array}$} & \multirow{2}{*}{$\begin{array}{c}\text { No of } \\
\text { studies }\end{array}$} & \multirow{2}{*}{$\begin{array}{c}\text { Relative } \\
\text { risk (95\% } \\
\text { Cl) }\end{array}$} & \multirow{2}{*}{$\begin{array}{c}1^{2} \\
(\%)\end{array}$} & \multicolumn{2}{|c|}{$\begin{array}{c}\mathbf{P} \text { for } \\
\text { heterogeneity }\end{array}$} \\
\hline & & & & * & $t$ & & & & * & $t$ & & & & * & $\dagger$ \\
\hline Yes & 10 & $\begin{array}{c}0.89(0.83 \text { to } \\
0.95)\end{array}$ & 19.4 & 0.26 & 0.22 & 7 & $\begin{array}{c}0.86(0.78 \text { to } \\
0.96)\end{array}$ & 0 & 0.75 & 0.04 & 7 & $\begin{array}{c}0.95 \text { (0.87 to } \\
1.04)\end{array}$ & 0 & 0.75 & 0.32 \\
\hline No & 6 & $\begin{array}{c}0.93(0.87 \text { to } \\
1.00)\end{array}$ & 0 & 0.91 & & 2 & $\begin{array}{c}1.10(0.95 \text { to } \\
1.28)\end{array}$ & 0 & 0.75 & & 2 & $\begin{array}{c}1.34(0.54 \text { to } \\
3.34)\end{array}$ & 45.0 & 0.18 & \\
\hline \multicolumn{16}{|l|}{$\begin{array}{l}\text { Physical } \\
\text { activity: }\end{array}$} \\
\hline Yes & 11 & $\begin{array}{c}0.90(0.85 \text { to } \\
0.96)\end{array}$ & 27.7 & 0.18 & 0.70 & 7 & $\begin{array}{c}0.91 \text { (0.79 to } \\
1.05)\end{array}$ & 40.0 & 0.13 & 0.56 & 7 & $\begin{array}{c}0.95 \text { (0.87 to } \\
1.04)\end{array}$ & 0 & 0.75 & 0.77 \\
\hline No & 5 & $\begin{array}{c}0.92 \text { (0.85 to } \\
0.99)\end{array}$ & 0 & 0.97 & & 2 & $\begin{array}{c}1.06(0.68 \text { to } \\
1.65)\end{array}$ & 0 & 0.79 & & 2 & $\begin{array}{c}1.34(0.54 \text { to } \\
3.34)\end{array}$ & 45.0 & 0.18 & \\
\hline \multicolumn{16}{|l|}{$\begin{array}{l}\text { Red, } \\
\text { processed } \\
\text { meat: }\end{array}$} \\
\hline Yes & 10 & $\begin{array}{c}0.89(0.84 \text { to } \\
0.95)\end{array}$ & 21.3 & 0.25 & 0.32 & 9 & $\begin{array}{c}0.93(0.82 \text { to } \\
1.05)\end{array}$ & 23 & 0.24 & NC & 9 & $\begin{array}{c}0.98(0.91 \text { to } \\
1.06)\end{array}$ & 0 & 0.60 & NC \\
\hline No & 6 & $\begin{array}{c}0.93(0.87 \text { to } \\
1.00)\end{array}$ & 0 & 0.86 & & 0 & - & - & - & & 0 & - & - & - & \\
\hline \multicolumn{16}{|l|}{$\begin{array}{l}\text { Dairy } \\
\text { products, } \\
\text { calcium: }\end{array}$} \\
\hline Yes & 10 & $\begin{array}{c}0.93 \text { (0.87 to } \\
0.98)\end{array}$ & 9.6 & 0.35 & 0.20 & 7 & $\begin{array}{c}0.94(0.82 \text { to } \\
1.07)\end{array}$ & 32.2 & 0.18 & 0.35 & 7 & $\begin{array}{c}0.98 \text { (0.91 to } \\
1.06)\end{array}$ & 0 & 0.51 & 0.81 \\
\hline No & 6 & $\begin{array}{c}0.87 \text { (0.82 to } \\
0.92)\end{array}$ & 0 & 0.74 & & 2 & $\begin{array}{c}0.69(0.40 \text { to } \\
1.19)\end{array}$ & 0 & 0.58 & & 2 & $\begin{array}{c}0.94 \text { (0.42 to } \\
2.07)\end{array}$ & 8.0 & 0.30 & \\
\hline \multicolumn{16}{|l|}{ Folate: } \\
\hline Yes & 7 & $\begin{array}{c}0.89 \text { (0.82 to } \\
0.95)\end{array}$ & 41.3 & 0.12 & 0.27 & 6 & $\begin{array}{c}0.90(0.77 \text { to } \\
1.06)\end{array}$ & 49.9 & 0.08 & 0.60 & 6 & $\begin{array}{c}0.98 \text { (0.90 to } \\
1.05)\end{array}$ & 0 & 0.62 & 0.59 \\
\hline No & 9 & $\begin{array}{c}0.93(0.87 \text { to } \\
1.00)\end{array}$ & 0 & 0.94 & & 3 & $\begin{array}{c}1.04(0.69 \text { to } \\
1.56)\end{array}$ & 0 & 0.93 & & 3 & $\begin{array}{c}1.33(0.61 \text { to } \\
2.87)\end{array}$ & 21.7 & 0.28 & \\
\hline \multicolumn{16}{|l|}{$\begin{array}{l}\text { Energy } \\
\text { intake: }\end{array}$} \\
\hline Yes & 11 & $\begin{array}{c}0.90(0.84 \text { to } \\
0.96)\end{array}$ & 27.3 & 0.18 & 0.62 & 9 & $\begin{array}{c}0.93(0.82 \text { to } \\
1.05)\end{array}$ & 23 & 0.24 & NC & 9 & $\begin{array}{c}0.98(0.91 \text { to } \\
1.06)\end{array}$ & 0 & 0.60 & NC \\
\hline No & 5 & $\begin{array}{c}0.92(0.86 \text { to } \\
0.98)\end{array}$ & 0 & 0.98 & & 0 & - & - & - & & 0 & - & - & - & \\
\hline
\end{tabular}

$\mathrm{NC}=$ not calculable.

*Within each subgroup.

†Between subgroups with meta-regression analysis.

$\ddagger$ Total dietary fibre: $\geq 15 v<15 \mathrm{~g} /$ day, fruit and vegetable fibre: $\geq 10 v<10 \mathrm{~g} /$ day. 


\begin{tabular}{|c|c|c|c|c|c|c|c|c|c|c|}
\hline \multirow[b]{2}{*}{ Subgroups } & \multicolumn{5}{|c|}{ Cereal fibre } & \multicolumn{5}{|c|}{ Whole grains } \\
\hline & $\begin{array}{l}\text { No of } \\
\text { studies }\end{array}$ & $\begin{array}{c}\text { Relative risk } \\
\quad(95 \% \mathrm{Cl})\end{array}$ & $I^{2}(\%)$ & $\begin{array}{c}\text { P for } \\
\text { heterogeneity }\end{array}$ & $\begin{array}{c}\mathrm{P} \text { for } \\
\text { heterogeneity } \dagger\end{array}$ & $\begin{array}{l}\text { No of } \\
\text { studies }\end{array}$ & $\begin{array}{c}\text { Relative risk } \\
\qquad(95 \% \mathrm{Cl})\end{array}$ & $I^{2}(\%)$ & $\begin{array}{c}\text { P for } \\
\text { heterogeneity* }\end{array}$ & $\begin{array}{c}\mathrm{P} \text { for } \\
\text { heterogeneity } \dagger\end{array}$ \\
\hline All studies & 8 & $\begin{array}{l}0.90(0.83 \text { to } \\
0.97)\end{array}$ & 0 & 0.78 & - & 6 & $\begin{array}{c}0.83 \text { (0.78 to } \\
0.89)\end{array}$ & 18.2 & 0.30 & - \\
\hline \multicolumn{11}{|l|}{$\begin{array}{l}\text { Duration of } \\
\text { follow-up: }\end{array}$} \\
\hline$<10$ years & 5 & $\begin{array}{c}0.90 \text { (0.82 to } \\
0.98)\end{array}$ & 0 & 0.42 & \multirow[t]{2}{*}{0.84} & 1 & $\begin{array}{c}0.73 \text { (0.63 to } \\
0.84)\end{array}$ & - & - & \multirow[t]{2}{*}{0.12} \\
\hline$\geq 10$ years & 3 & $\begin{array}{c}0.87 \text { (0.71 to } \\
1.08)\end{array}$ & 0 & 0.99 & & 5 & $\begin{array}{c}0.86 \text { ( } 0.80 \text { to } \\
0.92)\end{array}$ & 0 & 0.72 & \\
\hline \multicolumn{11}{|l|}{ Sex: } \\
\hline Men & 2 & $\begin{array}{c}0.92(0.80 \text { to } \\
1.06)\end{array}$ & 0 & 0.60 & \multirow[t]{2}{*}{0.69} & 3 & $\begin{array}{c}0.79 \text { (0.72 to } \\
0.87)\end{array}$ & 0 & 0.44 & \multirow[t]{2}{*}{0.14} \\
\hline Women & 5 & $\begin{array}{c}0.96 \text { ( } 0.83 \text { to } \\
1.11)\end{array}$ & 0 & 0.98 & & 5 & $\begin{array}{c}0.88 \text { (0.81 to } \\
0.95)\end{array}$ & 0 & 0.58 & \\
\hline \multicolumn{11}{|l|}{ Subsite: } \\
\hline Colon & 3 & $\begin{array}{c}1.03 \text { (0.80 to } \\
1.32)\end{array}$ & 0 & 0.45 & \multirow[t]{2}{*}{0.45} & 4 & $\begin{array}{l}0.86 \text { (0.79 to } \\
0.94)\end{array}$ & 0 & 0.58 & \multirow[t]{2}{*}{0.53} \\
\hline Rectum & 1 & $\begin{array}{c}1.39 \text { (0.78 to } \\
2.48)\end{array}$ & - & - & & 3 & $\begin{array}{c}0.80 \text { (0.56 to } \\
1.14)\end{array}$ & 90.5 & $<0.001$ & \\
\hline \multicolumn{11}{|l|}{$\begin{array}{l}\text { Geographical } \\
\text { location: }\end{array}$} \\
\hline Europe & 2 & $\begin{array}{c}0.94 \text { (0.73 to } \\
1.21)\end{array}$ & 0 & 0.48 & \multirow[t]{3}{*}{0.70} & 2 & $\begin{array}{c}0.87 \text { (0.78 to } \\
0.96)\end{array}$ & 58.8 & 0.12 & \multirow[t]{3}{*}{0.13} \\
\hline USA & 6 & $\begin{array}{c}0.89 \text { (0.82 to } \\
0.97)\end{array}$ & 0 & 0.65 & & 4 & $\begin{array}{l}0.79(0.72 \text { to } \\
0.86)\end{array}$ & 0 & 0.57 & \\
\hline Asia & 0 & - & - & - & & 0 & - & - & - & \\
\hline \multicolumn{11}{|l|}{ No of cases: } \\
\hline$<500$ & 3 & $\begin{array}{c}1.01(0.77 \text { to } \\
1.32)\end{array}$ & 0 & 0.99 & \multirow[t]{3}{*}{0.48} & 0 & & & & \multirow[t]{3}{*}{0.12} \\
\hline 500-1499 & 2 & $\begin{array}{c}0.87 \text { (0.71 to } \\
1.08)\end{array}$ & 0 & 0.92 & & 5 & $\begin{array}{c}0.86 \text { ( } 0.80 \text { to } \\
0.92)\end{array}$ & 0 & 0.72 & \\
\hline$\geq 1500$ & 3 & $\begin{array}{c}0.88(0.77 \text { to } \\
1.00)\end{array}$ & 35.1 & 0.21 & & 1 & $\begin{array}{c}0.73 \text { (0.63 to } \\
0.84)\end{array}$ & - & - & \\
\hline \multicolumn{11}{|l|}{$\begin{array}{l}\text { Range of } \\
\text { intake: }\end{array}$} \\
\hline $\begin{array}{l}<7 \text { to }<90 \\
\text { g/day } \neq\end{array}$ & 3 & $\begin{array}{c}0.91 \text { ( } 0.68 \text { to } \\
1.21)\end{array}$ & 0 & 0.85 & \multirow[t]{2}{*}{0.90} & 1 & $\begin{array}{c}0.73 \text { (0.63 to } \\
0.84)\end{array}$ & & & \multirow[t]{2}{*}{0.18} \\
\hline $\begin{array}{l}\geq 7 \text { to } \geq 90 \\
\text { g/day } \neq\end{array}$ & 5 & $\begin{array}{c}0.89(0.82 \text { to } \\
0.97)\end{array}$ & 0 & 0.45 & & 3 & $\begin{array}{c}0.87 \text { (0.80 to } \\
0.94)\end{array}$ & 0 & 0.39 & \\
\hline \multicolumn{11}{|c|}{ Adjustment for confounders } \\
\hline \multicolumn{11}{|l|}{ Alcohol: } \\
\hline Yes & 6 & $\begin{array}{c}0.93 \text { (0.84 to } \\
1.02)\end{array}$ & 0 & 0.98 & \multirow[t]{2}{*}{0.27} & 3 & $\begin{array}{c}0.86 \text { (0.79 to } \\
0.93)\end{array}$ & 0 & 0.92 & \multirow[t]{2}{*}{0.51} \\
\hline No & 2 & $\begin{array}{c}0.86 \text { (0.68 to } \\
1.08)\end{array}$ & 41.9 & 0.19 & & 3 & $\begin{array}{l}0.81 \text { ( } 0.70 \text { to } \\
0.93)\end{array}$ & 60.6 & 0.08 & \\
\hline \multicolumn{11}{|l|}{ Smoking: } \\
\hline Yes & 7 & $\begin{array}{c}0.89 \text { (0.82 to } \\
0.97)\end{array}$ & 0 & 0.76 & \multirow[t]{2}{*}{0.47} & 3 & $\begin{array}{c}0.79(0.71 \text { to } \\
0.87)\end{array}$ & 1.6 & 0.36 & \multirow[t]{2}{*}{0.21} \\
\hline No & 1 & $\begin{array}{c}1.02 \text { (0.73 to } \\
1.43)\end{array}$ & - & - & & 3 & $\begin{array}{c}0.87 \text { (0.80 to } \\
0.94)\end{array}$ & 0 & 0.39 & \\
\hline $\begin{array}{l}\text { Body mass } \\
\text { index, weight, } \\
\text { waist to hip } \\
\text { ratio: }\end{array}$ & & & & & & & & & & \\
\hline Yes & 7 & $\begin{array}{c}0.89(0.82 \text { to } \\
0.97)\end{array}$ & 0 & 0.76 & 0.27 & 4 & $\begin{array}{c}0.87(0.81 \text { to } \\
0.94)\end{array}$ & 0 & 0.82 & 0.09 \\
\hline
\end{tabular}


Table 4 (continued)

\begin{tabular}{|c|c|c|c|c|c|c|c|c|c|c|}
\hline \multirow[b]{2}{*}{ Subgroups } & \multicolumn{5}{|c|}{ Cereal fibre } & \multicolumn{5}{|c|}{ Whole grains } \\
\hline & $\begin{array}{l}\text { No of } \\
\text { studies }\end{array}$ & $\begin{array}{c}\text { Relative risk } \\
(95 \% \mathrm{Cl})\end{array}$ & $I^{2}(\%)$ & $\begin{array}{c}\text { P for } \\
\text { heterogeneity* }\end{array}$ & $\begin{array}{c}\text { P for } \\
\text { heterogeneity } \dagger\end{array}$ & $\begin{array}{c}\text { No of } \\
\text { studies }\end{array}$ & $\begin{array}{l}\text { Relative risk } \\
(95 \% \mathrm{Cl})\end{array}$ & $I^{2}(\%)$ & $\begin{array}{c}\text { P for } \\
\text { heterogeneity* }\end{array}$ & $\begin{array}{c}\mathrm{P} \text { for } \\
\text { heterogeneity }\end{array}$ \\
\hline No & 1 & $\begin{array}{c}1.02 \text { (0.73 to } \\
1.43)\end{array}$ & - & - & & 2 & $\begin{array}{c}0.75 \text { (0.67 to } \\
0.84)\end{array}$ & 0 & 0.52 & \\
\hline \multicolumn{11}{|l|}{$\begin{array}{l}\text { Physical } \\
\text { activity: }\end{array}$} \\
\hline Yes & 6 & $\begin{array}{c}0.89(0.81 \text { to } \\
0.96)\end{array}$ & 0 & 0.68 & \multirow[t]{2}{*}{0.38} & 4 & $\begin{array}{c}0.82(0.76 \text { to } \\
0.89)\end{array}$ & 20.1 & 0.29 & \multirow[t]{2}{*}{0.60} \\
\hline No & 2 & $\begin{array}{c}1.02(0.77 \text { to } \\
1.34)\end{array}$ & 0 & 0.97 & & 2 & $\begin{array}{c}0.86(0.73 \text { to } \\
1.01)\end{array}$ & 47.5 & 0.17 & \\
\hline \multicolumn{11}{|l|}{$\begin{array}{l}\text { Red, } \\
\text { processed } \\
\text { meat: }\end{array}$} \\
\hline Yes & 8 & $\begin{array}{c}0.90(0.83 \text { to } \\
0.97)\end{array}$ & 0 & 0.78 & \multirow[t]{2}{*}{ NC } & 3 & $\begin{array}{c}0.84(0.74 \text { to } \\
0.95)\end{array}$ & 64.0 & 0.06 & \multirow[t]{2}{*}{0.81} \\
\hline No & 0 & - & - & - & & 3 & $\begin{array}{c}0.82(0.74 \text { to } \\
0.91)\end{array}$ & 0 & 0.81 & \\
\hline \multicolumn{11}{|c|}{$\begin{array}{l}\text { Dairy products, } \\
\text { calcium: }\end{array}$} \\
\hline Yes & 6 & $\begin{array}{c}0.90(0.83 \text { to } \\
0.98)\end{array}$ & 0 & 0.56 & \multirow[t]{2}{*}{0.82} & 2 & $\begin{array}{c}0.82(0.65 \text { to } \\
1.03)\end{array}$ & 79.7 & 0.03 & \multirow[t]{2}{*}{0.79} \\
\hline No & 2 & $\begin{array}{c}0.85(0.59 \text { to } \\
1.23)\end{array}$ & 0 & 0.87 & & 4 & $\begin{array}{c}0.84(0.78 \text { to } \\
0.91)\end{array}$ & 0 & 0.81 & \\
\hline \multicolumn{11}{|l|}{ Folate: } \\
\hline Yes & 5 & $\begin{array}{c}0.88(0.81 \text { to } \\
0.96)\end{array}$ & 0 & 0.54 & \multirow[t]{2}{*}{0.38} & 1 & $\begin{array}{c}0.73(0.63 \text { to } \\
0.84)\end{array}$ & & & \multirow[t]{2}{*}{0.12} \\
\hline No & 3 & $\begin{array}{c}1.01(0.77 \text { to } \\
1.32)\end{array}$ & 0 & 0.99 & & 5 & $\begin{array}{c}0.86(0.80 \text { to } \\
0.92)\end{array}$ & 0 & 0.72 & \\
\hline \multicolumn{11}{|l|}{ Energy intake: } \\
\hline Yes & 6 & $\begin{array}{c}0.90(0.82 \text { to } \\
0.98)\end{array}$ & 0 & 0.56 & \multirow[t]{2}{*}{0.83} & 4 & $\begin{array}{c}0.83(0.74 \text { to } \\
0.92)\end{array}$ & 41.1 & 0.17 & \multirow[t]{2}{*}{0.91} \\
\hline No & 2 & $\begin{array}{c}0.87 \text { (0.71 to } \\
1.08)\end{array}$ & 0 & 0.92 & & 2 & $\begin{array}{c}0.85 \text { (0.77 to } \\
0.93)\end{array}$ & 0 & 0.35 & \\
\hline
\end{tabular}

$\mathrm{NC}=$ not calculable.

*Within each subgroup.

†Between subgroups with meta-regression analysis.

$\ddagger$ Cereal fibre: $\geq 7$ versus $<7 \mathrm{~g} /$ day, whole grains: $\geq 90$ versus $<90 \mathrm{~g} /$ day. 


\section{Figures}

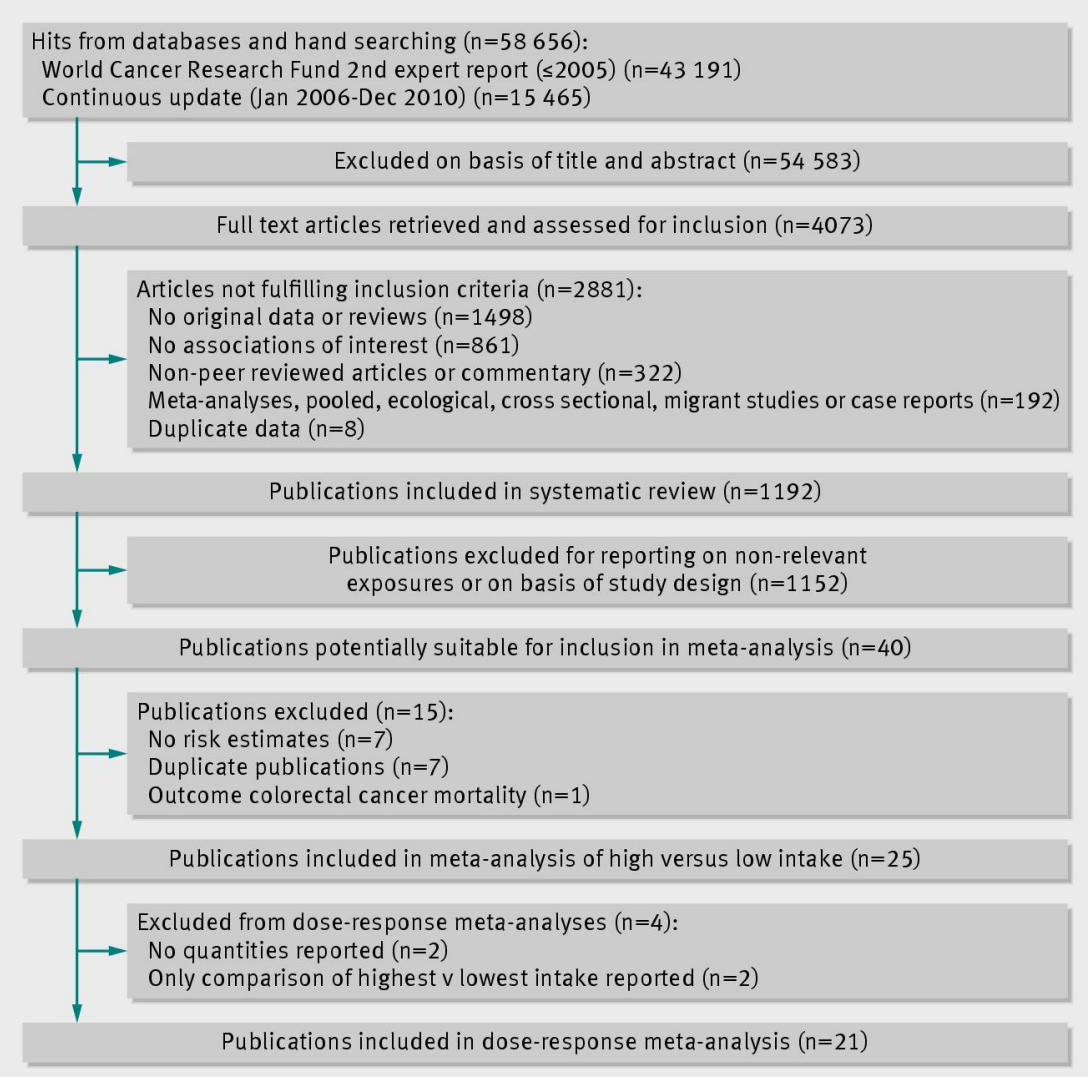

Fig 1 Flow chart of publications included in systematic review 
Study

Kabat $2008^{29}$ Nomura $2007^{28}$ Schatzkin $2007^{27}$ Wakai $2007^{26}$ McCarl $2006^{25}$ Otani $2006^{24}$ Shin $2006^{23}$ Bingham $2005^{8}$ Lin $2005^{22}$ Michels $2005^{21}$ (NHS) Michels $2005^{21}$ (HPFS) Sanjoaquin $2004^{20}$ Mai $2003^{18}$ Terry $2001^{17}$ Pietinen $1999^{16}$ Heilbrun $1989^{12}$ overall
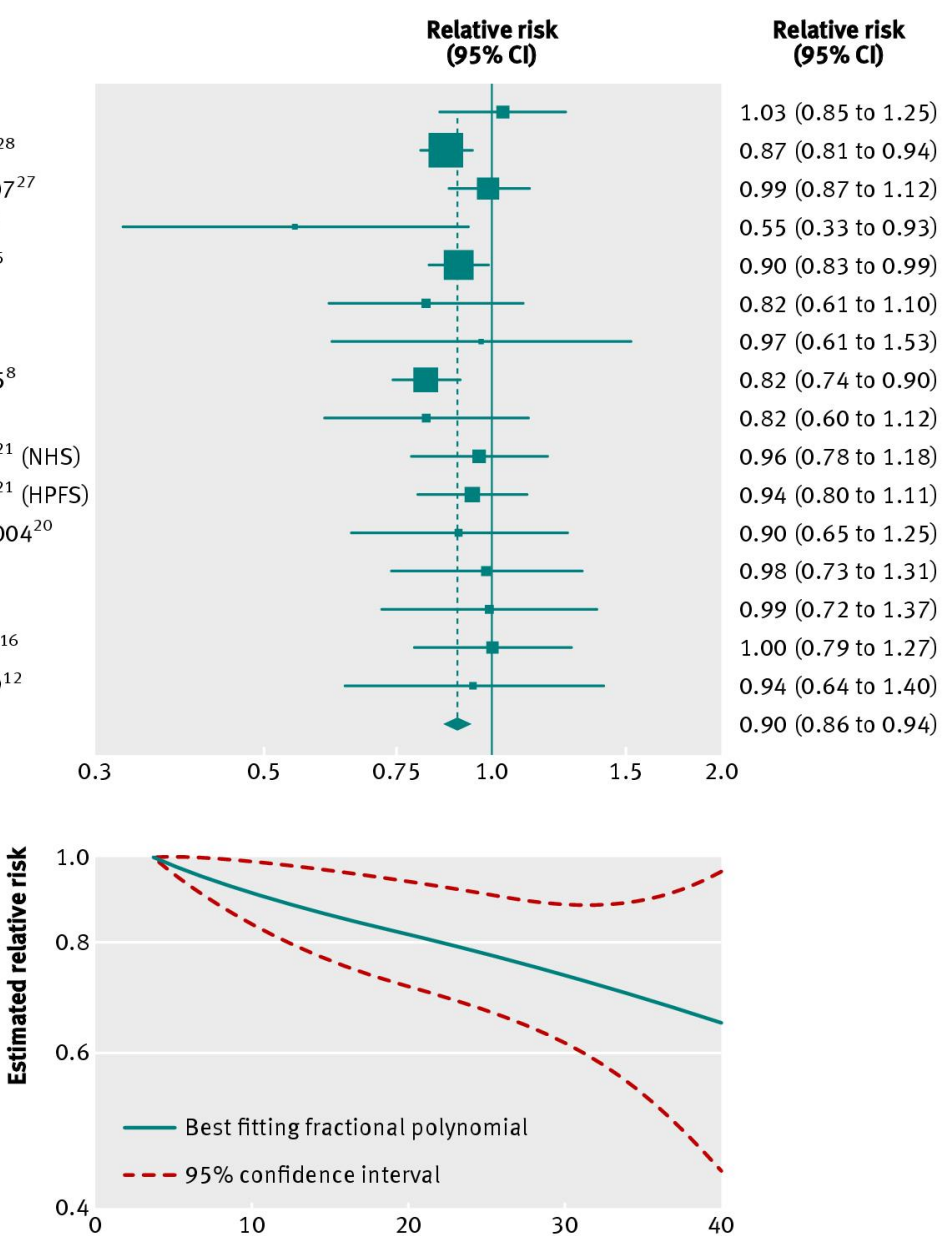

Dietary fibre (g/day)

Fig 2 Dose-response analyses between dietary fibre and risk of colorectal cancer. NHS=Nurses' Health Study; HPFS=Health Professionals Follow-up Study 


\section{Fruit fibre \\ Study}

Nomura $2007^{28}$ Schatzkin $2007^{27}$ Wakai $2007^{26}$ Bingham $2005^{8}$ Lin $2005^{22}$ Michels $2005^{21}$ (NHS) Michels $2005^{21}$ (HPFS) Mai $2003^{18}$ Terry $2001^{17}$ Overall

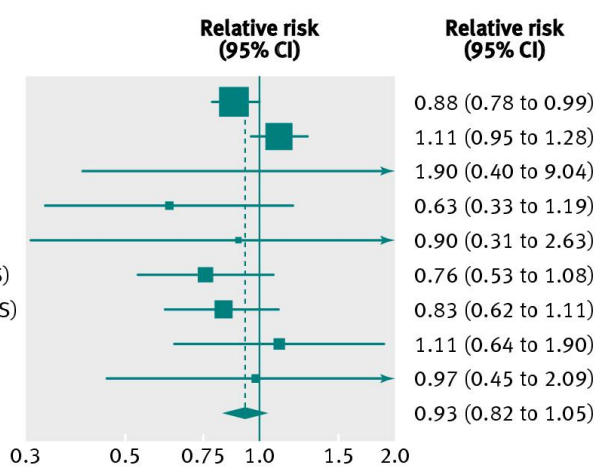

\section{Legume fibre}

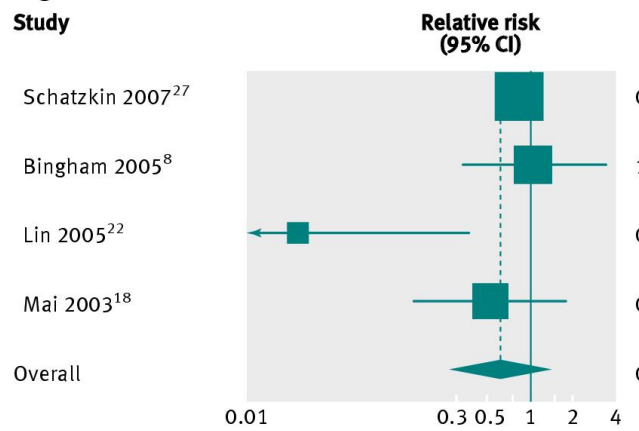

\section{Relative risk}

0.85 (0.65 to 1.11$)$

1.09 (0.34 to 3.53$)$

$0.02(0.00$ to 0.37$)$

$0.53(0.15$ to 1.86$)$

0.62 (0.27 to 1.42 )
Vegetable fibre

Study

Nomura $2007^{28}$ Schatzkin $2007^{27}$ Wakai $2007^{26}$ Bingham $2005^{8}$ Lin $2005^{22}$

Michels $2005^{21}$ (NHS) Michels $2005^{21}$ (HPFS) Mai $2003^{18}$ Terry $2001^{17}$ Overall

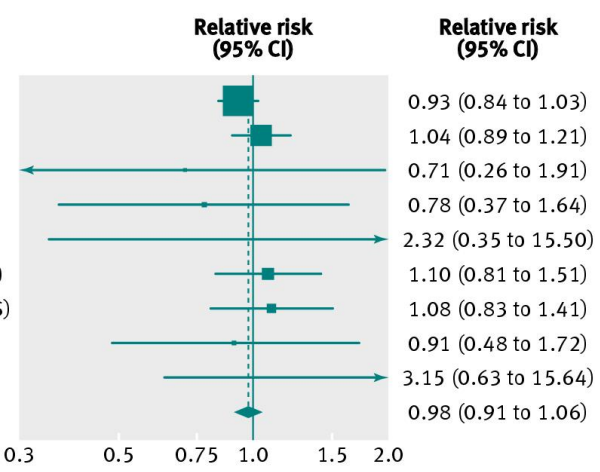

\section{Cereal fibre}

Study

\section{Nomura $2007^{28}$} Schatzkin $2007^{27}$ Bingham $2005^{8}$ Lin $2005^{22}$

Michels $2005^{21}$ (NHS) Michels $2005^{21}$ (HPFS) Mai $2003^{18}$ Terry $2001^{17}$ Overall

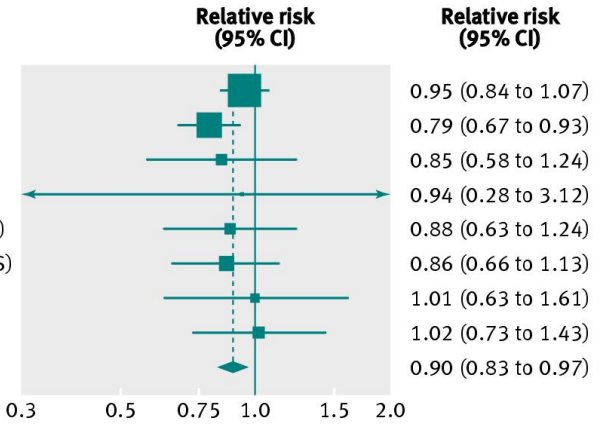

Fig 3 Risk of colorectal cancer according to fibre types. NHS=Nurses' Health Study; HPFS=Health Professionals Follow-up Study

Study

Fung $2010^{39}$ (HPFS) Fung $2010^{39}$ (NHS) Egeberg $2010^{38}$ Schatzkin $2007^{27}$ McCarl $2006^{25}$ Larsson $2005^{35}$ overall
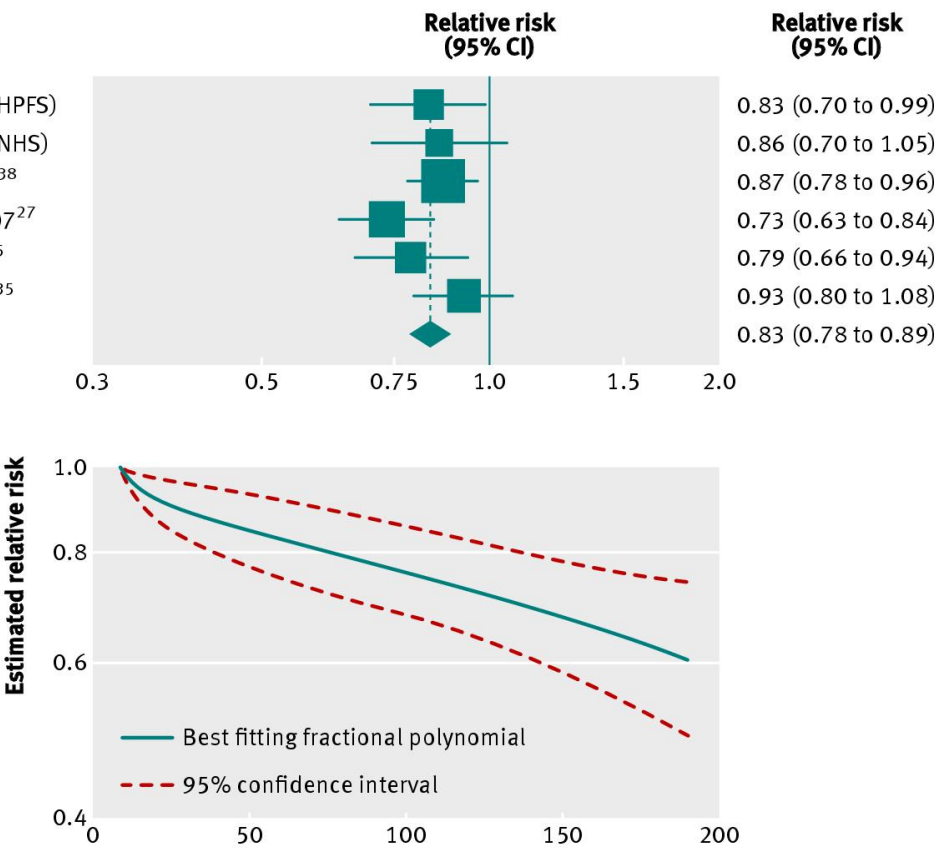

Whole grains (g/day)

Fig 4 Dose-response analyses between whole grains and risk of colorectal cancer. NHS=Nurses' Health Study; HPFS=Health Professionals Follow-up Study 